\title{
A thermodynamic description for physiological
}

\section{transmembrane transport [version 1; peer review: 1 approved,}

\section{1 approved with reservations]}

\author{
Marco Arieli Herrera-Valdez (iD) \\ Department of Mathematics, Facultad de Ciencias, Universidad Nacional Autonoma de Mexico, CDMX, 04510, Mexico
}

V1 First published: $14 \operatorname{Sep} 2018,7: 1468$

https://doi.org/10.12688/f1000research.16169.1

Second version: 21 Nov 2018, 7:1468

https://doi.org/10.12688/f1000research.16169.2

Latest published: 19 May 2021, 7:1468

https://doi.org/10.12688/f1000research.16169.3

\section{Abstract}

A generic formulation for both passive and active transmembrane transport is derived from basic thermodynamical principles. The derivation takes into account the energy required for the motion of molecules across membranes, and includes the possibility of modeling asymmetric flow. Transmembrane currents can then be described by the generic model in the case of electrogenic flow. As it is desirable in new models, it is possible to derive other well known expressions for transmembrane currents as particular cases of the generic formulation. For instance, the conductance-based formulation for current turns out to be a linear approximation of the generic current. Also, under suitable assumptions, other formulas for current based on electrodiffusion, like the constant field approximation by Goldman, can also be recovered from the generic formulation. The applicability of the generic formulations is illustrated first with fits to existing data, and after, with models of transmembrane potential dynamics for pacemaking cardiocytes and neurons. The generic formulations presented here provide a common ground for the biophysical study of physiological phenomena that depend on transmembrane transport.

\section{Keywords}

Transmembrane transport, ion channels, passive transport, active transport, rectification, bidirectional assymetric flow, AMPA-Kainate receptor, excitable cell

\section{Open Peer Review

Approval Status $\begin{gathered} \\ 1\end{gathered}$

version 3

(revision)

19 May 2021

version 2

(revision)

21 Nov 2018

version 1

14 Sep 2018

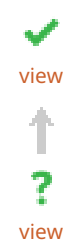

\section{view}

1. Kyle C.A. Wedgwood ID, University of Exeter, Exeter, UK

2. Moisés Santillán (D), Center for Research and Advanced Studies of the National Polytechnic Institute (CINVESTAV), Monterrey, Mexico

Any reports and responses or comments on the article can be found at the end of the article. 
Corresponding author: Marco Arieli Herrera-Valdez (marcoh@ciencias.unam.mx)

Author roles: Herrera-Valdez MA: Conceptualization, Data Curation, Formal Analysis, Funding Acquisition, Investigation, Methodology, Project Administration, Resources, Software, Validation, Visualization, Writing - Original Draft Preparation, Writing - Review \& Editing

Competing interests: No competing interests were disclosed.

Grant information: This work was supported by UNAM-PAPIIT IA208618.

The funders had no role in study design, data collection and analysis, decision to publish, or preparation of the manuscript.

Copyright: @ 2018 Herrera-Valdez MA. This is an open access article distributed under the terms of the Creative Commons Attribution License, which permits unrestricted use, distribution, and reproduction in any medium, provided the original work is properly cited.

How to cite this article: Herrera-Valdez MA. A thermodynamic description for physiological transmembrane transport [version 1; peer review: 1 approved, 1 approved with reservations] F1000Research 2018, 7:1468 https://doi.org/10.12688/f1000research.16169.1

First published: 14 Sep 2018, 7:1468 https://doi.org/10.12688/f1000research.16169.1 


\section{Introduction}

One of the most important physiological mechanisms underlying communication within and between cells is the transport of molecules across membranes. Molecules can cross membranes either passively (Stein \& Litman, 2014), or via active transport (Bennett, 1956). Molecules are passively transported across a membrane when they move along their (electro)chemical gradient and occurs through channels that may be spontaneously formed within the lipid bilayer (Blicher \& Heimburg, 2013), or lined by transmembrane proteins (Hille, 1992; Stein \& Litman, 2014) that may be selective for molecules of specific types (Almers \& McCleskey, 1984; Doyle et al., 1998; Favre et al., 1996). Therefore, passive transport is (electro)diffusive in nature. In contrast, active transport takes molecules against their electrochemical gradients, and is mediated by transmembrane proteins commonly called pumps (e.g. symporters, exchangers) that mechanically translocate the molecules they transport (Bennett, 1956; Ussing, 1949a; Ussing, 1949b). The energy for active transport of molecules may be obtained from biochemical reactions (e.g. ATPases, light-driven pumps) or from the electrochemical gradients of molecules transported in parallel to the molecule that is actively transported (SKou, 1965). One important functional distinction between channels and pumps is that the rate of transport for channels is generally several orders of magnitude faster than the rate for pump-mediated transport (Gadsby, 2009; Ussing, 1949c). Such differences are reflected in the sizes of different transmembrane currents typically observed in excitable cells (Herrera-Valdez \& Lega, 2011).

Theoretical models of transmembrane transport play a critical role in developing our understanding of the function and mechanisms underlying electrical signaling and cellular excitability (Barr, 1965; Cole, 1965; DiFrancesco \& Noble, 1985; Endresen et al., 2000; Gadsby, 2009; Goldman, 1943; Kell, 1979; Läuger, 1973; Stevens \& Tsien, 1979; Wiggins, 1985a; Wiggins, 1985b; Wiggins, 1985c), and some of its associated pathologies (Ashcroft, 2005; Marbán, 2002). The best known transmembrane transport models include the widely used conductance-based formulation from the seminal work of Hodgkin \& Huxley (1952), the Goldman-Hodgkin-Katz equation (Goldman, 1943; Hodgkin \& Katz, 1949; Pickard, 1976), and several other expressions for carrier and channel mediated transport with many different functional forms (DiFrancesco \& Noble, 1985; Rasmusson et al., 1990a; Rasmusson et al., 1990b; Rosenberg \& Wilbrandt, 1955). Other formulations for ionic transport across membranes derived from biophysical principles available in the literature include those in the seminal work by Jacquez \& Schultz (1974); Pickard, 1969; Pickard, 1976; see also Jacquez (1981) and similar work by Endresen et al. (2000), and those in the excellent book by Johnston et al. (1995). Such formulations describe the relationship between the activity and permeability of ions across membranes, and the transmembrane potential. However general models that describe physiological transport that include passive and active transport of charged or non-charged molecules, possibly including bidirectional but asymmetric flows, are still missing. The work presented here builds upon the results previously mentioned by describing transport macroscopically in terms of the energy required to move molecules across a membrane. The result is a generic formulation with a common functional form for both passive and active transport (Herrera-Valdez, 2014) that also includes a term that regulates the asymmetry in the flow (rectification).

The details of the derivation can be found are explained in the next section. Examples of fits to experimental data and features like asymmetric bidirectional flow. An application of the generic formulation is illustrated with models for the transmembrane potential dynamics in cardiac pacemaker cells and striatal fast spiking interneurons (Supplementary File 1) using the same functional forms for the currents. Derivations of formulas and specific examples of noncentral issues addressed in this article can be found in the Supplementary File 1.

An earlier version of this article is available on PeerJ as a preprint https://doi.org/10.7287/peerj.preprints.1312v8.

\section{Generic formulation for transmembrane flux and current}

Work required for transmembrane molecular fluxes

Consider a system consisting of a biological membrane surrounded by two aqueous compartments (e.g. extracellular and intracellular). Assume, to start with, that the compartments contain molecules of a single type $s\left(\right.$ e.g. $\mathrm{Na}^{+}, \mathrm{K}^{+}$, glucose), possibly in different concentrations. Let $\Delta G_{s}$ be the energy required for the transport of the molecules across the membrane in a specific direction (e.g. inside to outside). To write an expression for $\Delta G_{s}$ it is necessary to take the direction of motion of the $s$-molecules into account. To do so, label the extracellular and intracellular compartments as 0 and 1 , respectively, and let $c_{s}$ and $d_{s}$ represent the source and the destination compartments for the transport of the $s$-molecules. The pair $\left(c_{s}, d_{s}\right)=(0,1)$ represents inward transport and the pair $\left(c_{s}, d_{s}\right)=(1,0)$ represents outward transport. The work required to transport $n_{s}$ molecules of type $s$ from compartment $c_{s}$ to compartment $d_{s}$ can then be written as

$$
\Delta G_{s}=n_{s}\left(c_{s}-d_{s}\right)\left[\mathrm{kT} \ln \left(\frac{[s]_{0}}{[s]_{1}}\right)-\mathrm{q} z_{s} v\right],
$$

(Aidley, 1998; Blaustein et al., 2004; De Weer et al., 1988) where $\mathrm{q}, z_{s},[s]_{0}$, and $[s]_{1}$ represent the elementary charge, the valence, the extracellular, and the intracellular concentrations for the molecules of type $s$, respectively. Two particular cases are worth noticing. First, if $s$ is an ion, then $z_{s} \neq 0$ and Equation (1) becomes

$$
\Delta G_{s}=\mathrm{q} z_{s} n_{s}\left(c_{s}-d_{s}\right)\left(v_{s}-v\right),
$$

where $v$ is the Nernst potential for the $s$-molecules ${ }^{1}$ (Nernst, 1888). Second, if the $s$-molecules are not charged, then $z_{s}=0$ and the work required to move the $s$-type molecules from $c_{s}$ to $d_{s}$ simplifies to

${ }^{1}$ The transmembrane potential for which there is a zero net flux of s-ions across the membrane, as given by the Nernst-Planck equation, is

$$
v_{s}=\frac{\mathrm{kT}}{z_{s} \mathrm{q}} \log \left(\frac{[s]_{0}}{[s]_{1}}\right) \text {. }
$$




$$
\Delta G_{s}=n_{s}\left(c_{s}-d_{s}\right) \mathrm{kT} \ln \left(\frac{[s]_{0}}{[s]_{1}}\right) .
$$

If $\Delta G_{s}<0$, then the molecules can be transported passively (e.g. electrodiffusion), decreasing the electrochemical gradient for $s$ across the membrane. In contrast, if $\Delta G_{s}>0$, the transmembrane transport of $s$ from $c_{s}$ to $d_{s}$ is not thermodynamically favorable, which means the transport from $c_{s}$ to $d_{s}$ requires energy that is not available in the electrochemical gradient for $s$ (active transport). As a consequence, active transport of $s$ would increase the driving force for the motion of $s$ across the membrane.

\section{Joint transmembrane transport of different types of molecules}

To find an expression for $\Delta G$ that describes a more general transport mechanism, assume that transport takes place as single events in which molecules of $m$ different types move in parallel, or possibly sequentially (e.g. first $\mathrm{Na}^{+}$, then $\mathrm{K}^{+}$), across the membrane. Let $S$ be a set that represents the types of molecules that are jointly transported in a single event. For instance, for $\mathrm{Na}^{+}-\mathrm{H}^{+}$exchangers, $S=\{N a, H\}$, with $m=2$. The energy required to transport these molecules is the sum of the energies required to transport each of the molecules in $S$. In other words,

$$
\Delta G_{S}=\sum_{s \in S} \Delta G_{s}
$$

As before, transport is thermodynamically favorable when $\Delta G_{S} \leq 0$. If not, extra energy is required. To distinguish between these two cases, define the total energy of the transport mechanism as

$$
\Delta G=\delta_{\mathrm{Ext}} \Delta G_{\mathrm{Ext}}+\Delta G_{s}
$$

where $\delta_{\text {Ext }}=1$ if $\Delta G_{S}>0$, and 0 otherwise. In particular, for ATP-driven transport, the extra energy supplied by hydrolysis of ATP (De Weer et al., 1988; Tanford, 1981) is

$$
\Delta G_{\mathrm{ATP}}=\mathrm{q} \Delta G_{\mathrm{ATP}}^{0}+\mathrm{kT} \ln \left(\frac{[\mathrm{ADP}]\left[\mathrm{P}_{i}\right]}{[\mathrm{ATP}]}\right)=\mathrm{q} v_{\mathrm{ATP}},
$$

where $v_{\text {ATP }} \approx-450 \mathrm{mV}$ (Endresen et al., 2000), but could vary depending on the amounts of ATP, ADP, and $\mathrm{P}_{i}$ (De Weer et al., 1988). Similar expressions could be derived for active transport driven by light, or other sources of energy.

\section{Flux due to transmembrane transport}

The formulation in Equation (10) can be combined with Equation (1) to derive a generalized expression for flux and model different known mechanisms of physiological transmembrane transport, possibly combining the transport of different molecules simultaneously (e.g. Na-H exchange). In this case, the forward direction of the transport would be described by the combined forward transport of each of the different molecules under consideration. For instance, the source and target compartments for $\mathrm{Na}^{+}$and $\mathrm{Ca}^{2+}$ are different in $\mathrm{Na}-\mathrm{Ca}$ exchangers. The stoichiometry for the transport mediated by
$\mathrm{Na}-\mathrm{Ca}$ exchangers in the forward direction involves three $\mathrm{Na}^{+}$ molecules moving inward (along their electrochemical gradient) in exchange for one $\mathrm{Ca}^{2+}$ molecule moving outward (against their electrochemical gradient) (Mullins, 1979; Venetucci et al., 2007).

Let $\alpha$ and $\beta$ be the flux rates in the forward and backward directions, in units of molecules per ms per $\mu \mathrm{m}^{-2}$. These rates depend, a priori, on the energy required for the transport of the molecules in $S$. The net flux rate associated to the net transmembrane transport, can then be written as

$$
\Phi(\Delta G)=\alpha(\Delta G)-\beta(\Delta G)
$$

How do $\alpha$ and $\beta$ depend on $\Delta G$ ? The steady state relationship between the energy $\Delta G$ and the the forward and backward flow rates, hereby represented by $\alpha$ and $\beta$, can be written as

$$
\frac{\alpha}{\beta}(\Delta G)=\exp \left(-\frac{\Delta G}{\mathrm{kT}}\right),
$$

where $\mathrm{k}$ is Boltzmann's constant, and T the absolute temperature.

Assuming that $\alpha$ and $\beta$ are continuous functions, the rates $\alpha$ and $\beta$ can be rewritten as

$$
\alpha=r \exp \left(-b \frac{\Delta G}{\mathrm{kT}}\right), \quad \beta=r \exp \left((1-b) \frac{\Delta G}{\mathrm{kT}}\right),
$$

where $r$ (molecules per ms per $\mu \mathrm{m}^{-2}$ ) may depend on temperature (Sen \& Widdas, 1962), the transmembrane potential (Starace et al., 1997), the concentrations inside and outside of the membrane (Yue et al., 1990), and other factors (Novák $\&$ Tyson, 2008). Note that the functional form of the rates in Equations (9) are similar to those by Butler (1924); Erdey-Grúz \& Volmer (1930). Also, notice that the steady state relationship between $\alpha$ and $\beta$ in Equation (8) can be obtained from Equations (9), for any $r$ and any $b$. However, it should be the case that $r$ and $b$ vary in specific ranges depending on the physico-chemical characteristics of the pore through which molecules cross the membrane, and in general, on the transport mechanism. As mentioned earlier, the rate $r$ should be larger for electrodiffusive transport in comparison to the slower transport rates for pumps and other carrier proteins. If the parameter $b \in[0,1]$, then $b \Delta G$ and $(b-1) \Delta G$ have opposite signs and can be thought of as the energies required to the transport of the molecules in $S$ in the forward and backward directions, respectively, with $b$ biasing the transport in the forward direction when close to 1 , and in the backward direction when close to 0 (Figure 1).

The flux can then be written explicitly combining Equation (7) and Equations (9) to obtain,

$$
\Phi(\Delta G)=r\left[\exp \left(-b \frac{\Delta G}{\mathrm{kT}}\right)-\exp \left((1-b) \frac{\Delta G}{\mathrm{kT}}\right)\right] .
$$

Taking the above observations into account, it is possible to combine Equation (4) and Equation (5), to write an expression 


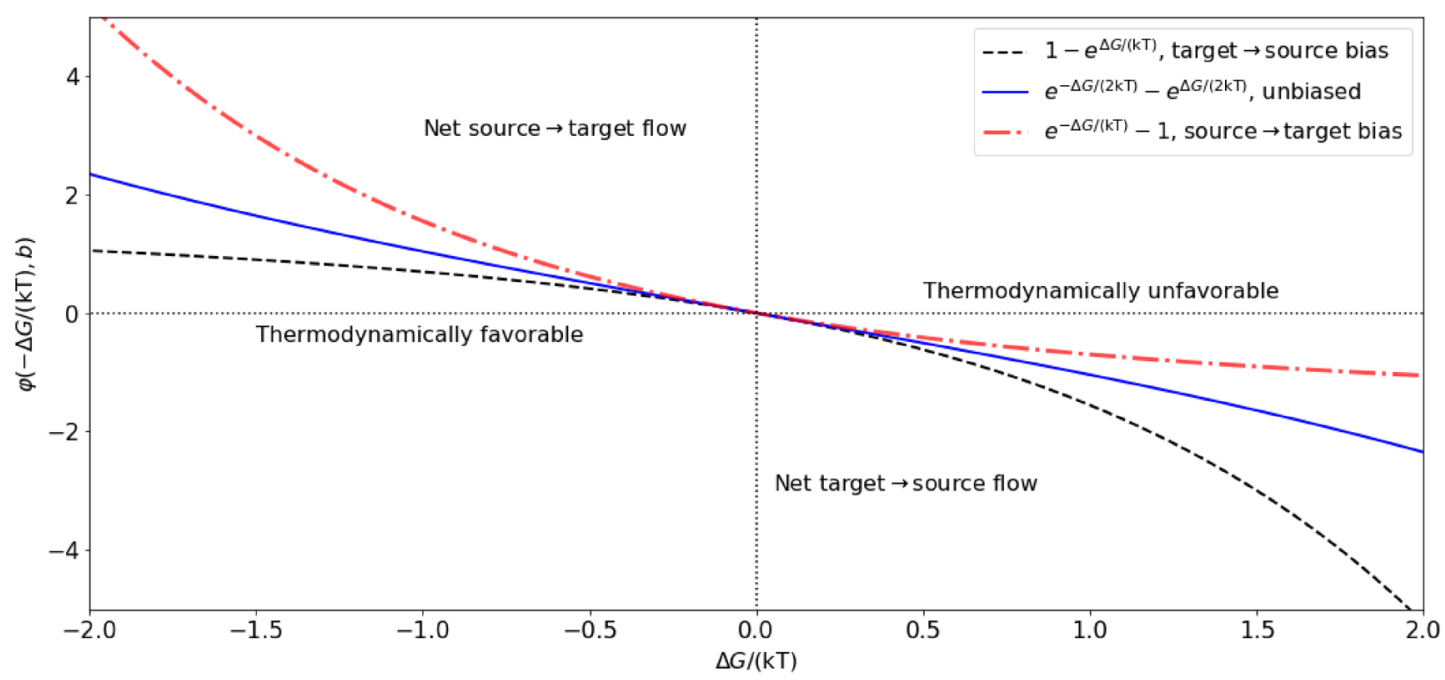

Figure 1. Fluxes biased in the target $\rightarrow$ source (backward, $b=0.1$, black dashed line), source $\rightarrow$ target (forward, $b=0.9$, red dash-dot line), or showing no rectification $(\boldsymbol{b}=\mathbf{0 . 5}$, blue solid line). See Table 1 for examples.

similar to Equation (8) for the steady state balance between the forward and backward transport of all the molecules in $S$.

\section{Flux and current}

Substitution of the formulas for $\Delta G$ from Equation (4) Equation (5) into Equation (10), the flux rate resulting from simultaneously transporting molecules in $S$ across the membrane can be written explicitly

$\Phi=r\left[\prod_{s \in S}\left(\frac{[s]_{0}}{[s]_{1}}\right)^{b b_{s}\left(d_{s}-c_{s}\right)} \exp \left(b \frac{\eta v-\delta_{\text {Extrat }} v_{\text {Extra }}}{v_{\mathrm{T}}}\right)-\prod_{s \in S}\left(\frac{[s]_{0}}{[s]_{1}}\right)^{(b-1) n_{s}\left(d_{s}-c_{s}\right)} \exp \left((b-1) \frac{\eta v-\delta_{\text {Extra }} v_{\text {Extra }}}{v_{\mathrm{T}}}\right)\right]$,

where $v_{\mathrm{T}}=\mathrm{kT} / \mathrm{q}$ and

$$
\eta=\sum_{s \in S} n_{s}\left(c_{s}-d_{s}\right) z_{s}
$$

represents the net number of charges moved across the membrane.

If the transport is electrogenic, then the product $\mathrm{q} \eta$ (in Coulombs) represents the net charge moved across the membrane, relative to the extracellular compartment. Non electrogenic transport yields $\eta=0$, which means the flow does not depend on the transmembrane potential, and

$$
\Phi=r\left[\prod_{s \in S}\left(\frac{[s]_{0}}{[s]_{1}}\right)^{b b_{s}\left(d_{s}-c_{s}\right)} \exp \left(-b \frac{\delta_{\mathrm{Extra}} v_{\mathrm{Extra}}}{v_{\mathrm{T}}}\right)-\prod_{s \in S}\left(\frac{[s]_{0}}{[s]_{1}}\right)^{(b-1) n_{s}\left(d_{s}-c_{s}\right)} \exp \left((1-b) \frac{\delta_{\mathrm{Exrar}} v_{\mathrm{Extra}}}{v_{\mathrm{T}}}\right)\right] .
$$

If only ions are involved in the transport, the flux simplifies to

$$
\Phi=r\left\{\exp \left[b\left(\frac{\eta v-v_{o}}{v_{\mathrm{T}}}\right)\right]-\exp \left[(b-1)\left(\frac{\eta v-v_{o}}{v_{\mathrm{T}}}\right)\right]\right\},
$$

where

$$
v_{o}=\delta_{\mathrm{Ext}} v_{\mathrm{Ext}}+\sum_{s \in S} n_{s} z_{s}\left(c_{s}-d_{s}\right) v_{s} .
$$

The quantity $v_{o} / \eta$ can be thought of as a reversal potential. If $\eta<0$, then positive charge is transported inward, or negative charge is transported outward. In contrast, $\eta>0$ means that positive charge is transported outward or negative charge transported inward. For instance, inward electrodiffusion of single $\mathrm{Na}^{+}$ions gives an $\eta=-1$, which can be thought of as loosing one positive charge from the extracellular compartment in each transport event (see Table 1). In particular, for electrodiffusive (passive) transport of ions of type $l, v_{o}$ reduces to $n_{l} z_{l}\left(c_{l}-d_{l}\right)$ $v_{l}$. A list with examples of energies and total charge movements for different transport mechanisms can be found in Table 1.

The first, more complex, form of the flux in Equation (13) could be useful when working with models for which changes in the concentrations of different molecules are relevant.

Transmembrane current. The flux that results in electrogenic transport (Equation (13) and Equation (14)) can be converted to current density after multiplication by $q \eta$. In short form,

$$
i=\mathrm{q} \eta \Phi
$$

with $\mathrm{q} r$ in amperes $/ \mathrm{m}^{2}$ or equivalent units.

Substitution of Equation (13) or Equation (14) into Equation (16) yields a general formula for the current generated by transmembrane ionic flux (Figure 2), that uses the same functional form for channels (protein or lipid) and pumps. Recall that Equation (16) can also be written explicitly in terms of the 
Table 1. Energy required for transmembrane transport mediated by different passive and active mechanisms.

\begin{tabular}{|c|c|c|c|c|c|c|c|c|c|}
\hline $\begin{array}{l}\text { Pump or } \\
\text { channel }\end{array}$ & $\begin{array}{l}\text { Molecule } \\
\text { (s) }\end{array}$ & $n_{s}$ & $c_{s}$ & $d_{s}$ & $c_{s}-d_{s}$ & $\Delta G_{s}=q n_{s}\left(c_{s}-d_{s}\right)\left[\mathrm{kTlog}\left(\frac{[s]_{0}}{[s]_{1}}\right)-q z_{s} v\right]$ & $\eta$ & $v_{0}$ & $\alpha / \beta=\exp \left(-\frac{\Delta G}{\mathrm{kT}}\right)$ \\
\hline $\begin{array}{l}\mathrm{Cl}^{-} \\
\text {channel }\end{array}$ & $\mathrm{Cl}^{-}$ & 1 & 0 & 1 & -1 & $\Delta G_{\mathrm{Cl}}=\mathrm{q}\left(v_{\mathrm{Cl}}-v\right)$ & 1 & $v_{\mathrm{Cl}}$ & $\left(\frac{[C l]_{1}}{[C l]_{0}}\right) \exp \left(\frac{v}{v_{\mathrm{T}}}\right)$ \\
\hline $\mathrm{K}^{+}$channel & $\mathrm{K}^{+}$ & 1 & 1 & 0 & 1 & $\Delta G_{K}=q\left(v_{k}-v\right)$ & 1 & $v_{\mathrm{K}}$ & $\left(\frac{[\mathrm{K}]_{1}}{[\mathrm{~K}]_{0}}\right) \exp \left(\frac{v}{v_{\mathrm{T}}}\right)$ \\
\hline $\begin{array}{l}\mathrm{Na}^{+} \\
\text {channel }\end{array}$ & $\mathrm{Na}^{+}$ & 1 & 0 & 1 & -1 & $\Delta G_{\mathrm{Na}}=-q\left(v_{\mathrm{Na}}-v\right)$ & -1 & $-V_{\mathrm{Na}}$ & $\left(\frac{[N a]_{0}}{[N a]_{1}}\right) \exp \left(-\frac{v}{v_{\mathrm{T}}}\right)$ \\
\hline $\begin{array}{l}\mathrm{Ca}^{2+} \\
\text { channel }\end{array}$ & $\mathrm{Ca}^{2+}$ & 1 & 0 & 1 & -1 & $\Delta G_{\mathrm{Ca}}=-2 \mathrm{q}\left(v_{\mathrm{Ca}}-v\right)$ & -2 & $-2 v_{C a}$ & $\left(\frac{[C a]_{0}}{[C a]_{1}}\right) \exp \left(-2 \frac{v}{v_{\mathrm{T}}}\right)$ \\
\hline $\begin{array}{l}\mathrm{Na}^{+}-\mathrm{K}^{+} \\
\text {ATPase }\end{array}$ & $\begin{array}{l}\mathrm{Na}^{+} \\
\mathrm{K}^{+}\end{array}$ & $\begin{array}{l}3 \\
2\end{array}$ & $\begin{array}{l}1 \\
0\end{array}$ & $\begin{array}{l}0 \\
1\end{array}$ & $\begin{array}{c}1 \\
-1\end{array}$ & $\begin{array}{l}\Delta G_{\mathrm{Na}}=3 q\left(v_{\mathrm{Na}}-v\right) \\
\Delta G_{\mathrm{K}}=-2 q\left(v_{\mathrm{K}}-v\right)\end{array}$ & 1 & $v_{\text {ATP }}+3 v_{\mathrm{Na}}-2 v_{\mathrm{K}}$ & $\left(\frac{[\mathrm{Na}]_{1}}{[\mathrm{Na}]_{0}}\right)^{3}\left(\frac{[\mathrm{K}]_{0}}{[\mathrm{~K}]_{1}}\right)^{2} \exp \left(\frac{v-v_{\mathrm{ATP}}}{v_{\mathrm{T}}}\right)$ \\
\hline $\begin{array}{l}\mathrm{Ca}^{2+} \\
\text { ATPase }\end{array}$ & $\mathrm{Ca}^{2+}$ & 1 & 1 & 0 & 1 & $\Delta G_{\mathrm{Ca}}=2 \mathrm{q}\left(v_{\mathrm{Ca}}-v\right)$ & 2 & $v_{\text {ATP }}+2 v_{\mathrm{Ca}}$ & $\left(\frac{[C a]_{1}}{[C a]_{0}}\right) \exp \left(\frac{2 v-v_{\text {ATP }}}{v_{\mathrm{T}}}\right)$ \\
\hline $\mathrm{H}^{+}$ATPase & $\mathrm{H}^{+}$ & 1 & 1 & 0 & 1 & $\Delta G_{H}=q\left(v_{H}-v\right)$ & 1 & $V_{\text {ATP }}+V_{H}$ & $\left(\frac{[H]_{1}}{[H]_{0}}\right) \exp \left(\frac{v-v_{\mathrm{ATP}}}{v_{\mathrm{T}}}\right)$ \\
\hline $\begin{array}{l}\mathrm{Na}^{+}-\mathrm{Ca}^{2+} \\
\text { exchanger }\end{array}$ & $\begin{array}{l}\mathrm{Na}^{+} \\
\mathrm{Ca}^{2+}\end{array}$ & $\begin{array}{l}3 \\
1\end{array}$ & $\begin{array}{l}0 \\
1\end{array}$ & $\begin{array}{l}1 \\
0\end{array}$ & $\begin{array}{c}-1 \\
1\end{array}$ & $\begin{aligned} \Delta G_{\mathrm{Na}} & =-3 q\left(v_{\mathrm{Na}}-v\right) \\
\Delta G_{\mathrm{Ca}} & =2 \mathrm{q}\left(v_{\mathrm{Ca}}-v\right)\end{aligned}$ & -1 & $2 v_{\mathrm{Ca}}-3 v_{\mathrm{Na}}$ & $\left(\frac{[\mathrm{Na}]_{1}}{[\mathrm{Na}]_{0}}\right)^{3}\left(\frac{[\mathrm{Ca}]_{0}}{[\mathrm{Ca}]_{1}}\right) \exp \left(-\frac{v}{v_{\mathrm{T}}}\right)$ \\
\hline $\begin{array}{l}\mathrm{Na}^{+}-I^{-} \\
\text {symporter }\end{array}$ & $\begin{array}{l}\mathrm{Na}^{+} \\
\mathrm{I}^{-1}\end{array}$ & $\begin{array}{l}2 \\
1\end{array}$ & $\begin{array}{l}0 \\
0\end{array}$ & $\begin{array}{l}1 \\
1\end{array}$ & $\begin{array}{l}-1 \\
-1\end{array}$ & $\begin{aligned} \Delta G_{\mathrm{Na}} & =-2 q\left(v_{\mathrm{Na}}-v\right) \\
\Delta G_{1} & =-q\left(v_{1}-v\right)\end{aligned}$ & -1 & $-v_{1}-2 v_{\mathrm{Na}}$ & $\left(\frac{[\mathrm{Na}]_{1}}{[\mathrm{Na}]_{0}}\right)^{2}\left(\frac{[\mathrm{I}]_{1}}{[\mathrm{I}]_{0}}\right) \exp \left(-\frac{v}{v_{\mathrm{T}}}\right)$ \\
\hline $\begin{array}{l}\mathrm{Na}^{+}-\mathrm{H}^{+} \\
\text {exchanger }\end{array}$ & $\begin{array}{l}\mathrm{Na}^{+} \\
\mathrm{H}^{+}\end{array}$ & $\begin{array}{l}1 \\
1\end{array}$ & $\begin{array}{l}0 \\
1\end{array}$ & $\begin{array}{l}1 \\
0\end{array}$ & $\begin{array}{c}-1 \\
1\end{array}$ & $\begin{aligned} \Delta G_{\mathrm{Na}} & =-q\left(v_{\mathrm{Na}}-v\right) \\
\Delta G_{\mathrm{H}} & =q\left(v_{\mathrm{H}}-v\right)\end{aligned}$ & 0 & $V_{\mathrm{H}}-V_{\mathrm{Na}}$ & $\left(\frac{[\mathrm{H}]_{1}}{[\mathrm{H}]_{0}}\right)\left(\frac{[\mathrm{Na}]_{0}}{[\mathrm{Na}]_{1}}\right)$ \\
\hline $\begin{array}{l}\mathrm{K}^{+}-\mathrm{Cl}^{-} \\
\text {symporter }\end{array}$ & $\begin{array}{l}\mathrm{K}^{+} \\
\mathrm{Cl}^{-}\end{array}$ & $\begin{array}{l}1 \\
1\end{array}$ & $\begin{array}{l}1 \\
1\end{array}$ & $\begin{array}{l}0 \\
0\end{array}$ & $\begin{array}{l}1 \\
1\end{array}$ & $\begin{array}{c}\Delta G_{\mathrm{K}}=\mathrm{q}\left(v_{\mathrm{K}}-v\right) \\
\Delta G_{\mathrm{Cl}}=-\mathrm{q}\left(v_{\mathrm{Cl}}-v\right)\end{array}$ & 0 & $v_{K}-v_{C l}$ & $\left(\frac{[\mathrm{K}]_{1}}{[\mathrm{~K}]_{0}}\right)\left(\frac{[\mathrm{Cl}]_{1}}{[\mathrm{Cl}]_{0}}\right)$ \\
\hline $\begin{array}{l}\mathrm{Na}^{+}-\mathrm{K}^{+}-\mathrm{Cl}^{-} \\
\text {symporter }\end{array}$ & $\begin{array}{l}\mathrm{Na}^{+} \\
\mathrm{K}^{+} \\
\mathrm{Cl}^{-}\end{array}$ & $\begin{array}{l}1 \\
1 \\
2\end{array}$ & $\begin{array}{l}0 \\
0 \\
0\end{array}$ & $\begin{array}{l}1 \\
1 \\
1\end{array}$ & $\begin{array}{l}-1 \\
-1 \\
-1\end{array}$ & $\begin{aligned} \Delta G_{\mathrm{Na}} & =-q\left(v_{\mathrm{Na}}-v\right) \\
\Delta G_{\mathrm{K}} & =-q\left(v_{\mathrm{K}}-v\right) \\
\Delta G_{\mathrm{Cl}} & =2 \mathrm{q}\left(v_{\mathrm{Cl}}-v\right)\end{aligned}$ & 0 & $2 v_{\mathrm{Cl}}-v_{\mathrm{Na}}-v_{\mathrm{K}}$ & $\left(\frac{[\mathrm{Na}]_{0}}{[\mathrm{Na}]_{1}}\right)\left(\frac{[\mathrm{K}]_{0}}{[\mathrm{~K}]_{1}}\right)\left(\frac{[\mathrm{Cl}]_{1}}{[\mathrm{Cl}]_{0}}\right)^{2}$ \\
\hline
\end{tabular}

transmembrane concentrations of one or more of the ions involved using Equation (13). It is possible to derive expressions for $r$ that take into account biophysical variables like temperature and the shape and length of the pore through which the molecules cross (Endresen et al., 2000; Pickard, 1969).

\section{Special cases and examples}

A number of nontrivial and important properties of transmembrane ionic currents, including rectification, are also described by Equation (16). Also, different models for current already in the literature can be obtained by making approximations or setting particular cases from Equation (16). Examples include electrodiffusive currents that result from integration of the Nernst-Planck equation along the length of membrane pore (Jacquez \& Schultz, 1974; Johnston et al., 1995; Pickard, 1969). Of particular interest, conductance-based currents are linear approximations of the formulation (16), around the reversal potential for the current. 


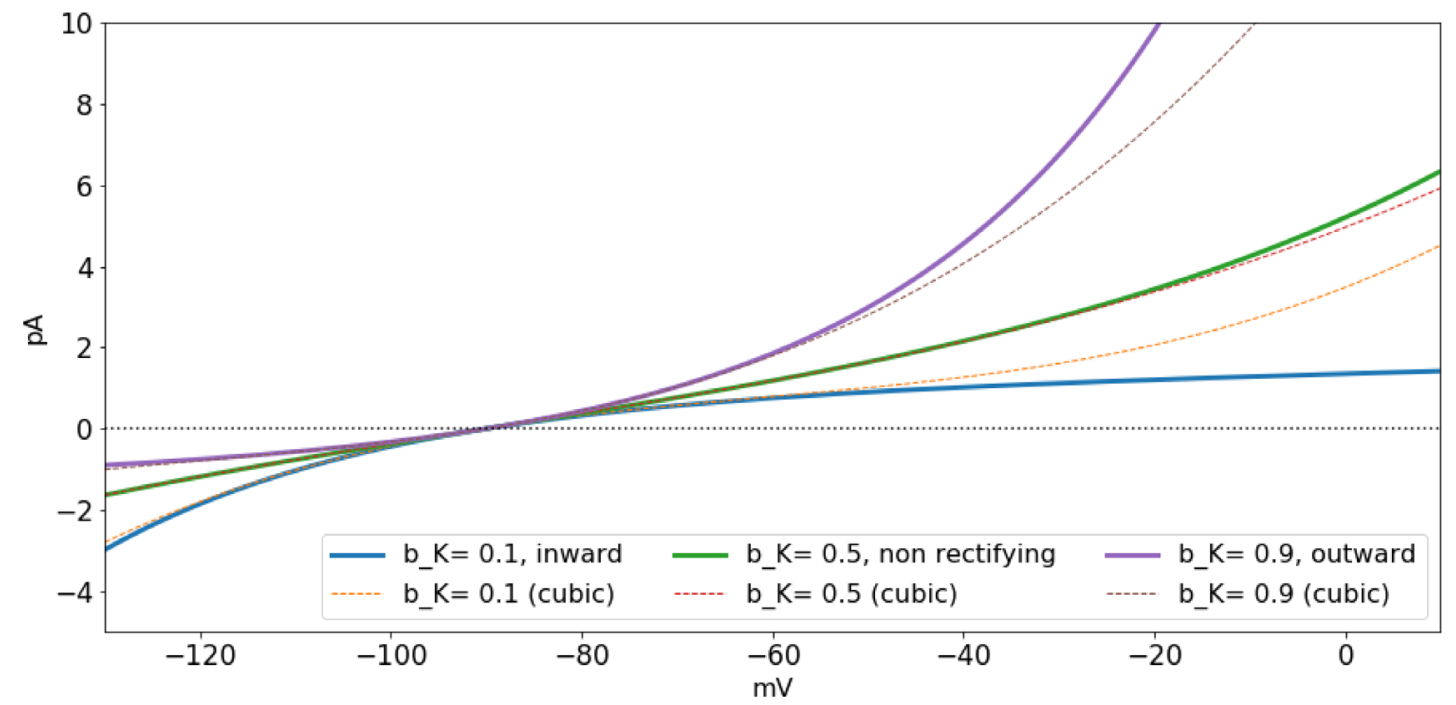

Figure 2. Fluxes for K-electrodiffusion for $\boldsymbol{b}_{\mathrm{K}} \in\{\mathbf{0 . 1}, \mathbf{0 . 5}, \mathbf{0 . 9}\}$ and their cubic approximations. Inward rectification occurs for $b_{K}<1 / 2$ and outward rectification for $b_{\mathrm{K}}>1 / 2$ and $\mathrm{q} r_{\mathrm{K}} N_{\mathrm{K}}=1$.

Lower order approximations to the generic formulation and conductance based models. Conductance-based currents (Hodgkin \& Huxley, 1952) are linear approximations of the generic current from Equation (16), around the reversal potential $v_{o} / \eta$. To see this, use Taylor's theorem (Courant \& John, 2012; Spivak, 2018) to rewrite the generic current from Equation (16) as a series around $v_{o}$

$$
i=\mathrm{q} \eta r\left[\left(\frac{\eta v-v_{o}}{v_{\mathrm{T}}}\right)+\left(b-\frac{1}{2}\right)\left(\frac{\eta v-v_{o}}{v_{\mathrm{T}}}\right)^{2}+\left(\frac{3 b^{2}-3 b+1}{3 !}\right)\left(\frac{\eta v-v_{o}}{v_{\mathrm{T}}}\right)^{3}+\ldots\right] .
$$

Truncation of the series to first order gives

$$
i \approx g\left(v-\frac{v_{o}}{\eta}\right)
$$

where $g=\eta^{2} \mathrm{q} r / v_{\mathrm{T}}$ is in units of $\mathrm{nS} / \mu \mathrm{m}^{2}$, which has the functional form of the conductance-based current used in the Hodgkin \& Huxley (1952) model. For instance, the linear approximation for the current through an open sodium channels around $v_{\mathrm{Na}}$ in Equation (18) gives $g_{\mathrm{Na}}=\mathrm{q} r_{\mathrm{Na}} / v_{\mathrm{T}}$, and $v_{o}=\eta_{\mathrm{Na}} v_{\mathrm{Na}}$, with $\eta_{\mathrm{Na}}=-1$, so that $i_{\mathrm{Na}} \approx g_{\mathrm{Na}}\left(v-v_{\mathrm{Na}}\right)$.

Notice that third order approximations to Equation (14) can also capture rectification. In contrast, first order approximations (conductance-based models) cannot capture rectification.

Rectification results from asymmetric bidirectional flow. The flux of molecules across the membrane can be biased in either the outward or the inward direction when mediated by proteins. This was first called "anomalous rectification" by Katz (1949), who noticed that $\mathrm{K}^{+}$flows through muscle membranes more easily in the inward, than in the outward direction (Adrian, 1969; Armstrong \& Binstock, 1965). It was later found that some $\mathrm{K}^{+}$channels display the bias in the opposite direction (Woodbury, 1971). The former type of $\mathrm{K}^{+}$current rectification is called inward, and the latter outward.
Rectification is a bias in either of the two directions of transport, which may result from changes in the structure of the proteins or pores through which the molecules cross the membrane (Hollmann et al., 1991; Riedelsberger et al., 2015). The type of rectification (inward or outward) depends on what molecules are being transported and on the structure of the proteins mediating the transport. Rectification is therefore not only a property of ions, as shown by molecules like glucose, which may cross membranes via GLUT transporters bidirectionally, but asymmetrically, even when the glucose concentration is balanced across the membrane (Lowe \& Walmsley, 1986).

Rectification can be described by Equation (13) by setting $b$ to values different from $1 / 2$, and becomes more pronounced as $b$ is closer to either 0 or 1 . These values represent biases in the transport toward the source, or the target compartment, respectively. As a consequence, rectification yields an asymmetry in the graph of $\alpha-\beta$ as a function of $\Delta G$ (Figure 2). For electrogenic transport, rectification can be thought of as an asymmetric relationship between current flow and voltage, with respect to the reversal potential $v_{o}$. The particular case $b=1 / 2$ (non-rectifying) yields a functional form for current similar to that proposed by Pickard (1969), and later reproduced by (Endresen et al., 2000), namely

$$
i=2 \mathrm{q} \eta r \sinh \left(\frac{\eta v-v_{o}}{2 v_{\mathrm{T}}}\right) \text {. }
$$

From here on, subscripts will be used to represent different transport mechanisms. For instance, the current for a $\mathrm{Na}-\mathrm{Ca}$ pump will be written as $i_{\mathrm{NaCa}}$.

Electrodiffusion of $\mathrm{K}^{+}$through channels $\left(\eta=1\right.$ and $\left.v_{o}=v_{\mathrm{K}}\right)$, is outward for $v>v_{\mathrm{K}}$, and inward for $v<v_{\mathrm{K}}$. The $\mathrm{K}^{+}$current through the open pore is therefore

$$
i_{\mathrm{K}}=\mathrm{q} r_{\mathrm{K}}\left\{\exp \left[b_{\mathrm{K}}\left(\frac{v-v_{K}}{v_{\mathrm{T}}}\right)\right]-\exp \left[\left(b_{\mathrm{K}}-1\right)\left(\frac{v-v_{K}}{v_{\mathrm{T}}}\right)\right]\right\} .
$$


Current flow through inward rectifier channels (Riedelsberger et al., 2015) can be fit to values of $b_{\mathrm{K}}<1 / 2$. For instance,

$$
i_{\mathrm{K} i n}=\mathrm{q} r_{\mathrm{K}}\left[1-\exp \left(\frac{v_{\mathrm{K}}-v}{v_{\mathrm{T}}}\right)\right], \quad\left(b_{\mathrm{K}}=0\right),
$$

describes a current with limited flow of $\mathrm{K}^{+}$in the outward direction, similar to the currents described originally by Katz (1949). Analogously, $b_{\mathrm{K}}>1 / 2$ limits the inward flow. For example, the current

$$
i_{\mathrm{K} o u t}=\mathrm{q} r_{\mathrm{K}}\left[\exp \left(\frac{v-v_{\mathrm{K}}}{v_{\mathrm{T}}}\right)-1\right], \quad\left(b_{\mathrm{K}}=1\right),
$$

describes outward rectification (Riedelsberger et al., 2015).

Based on the work of Riedelsberger et al. (2015) on $\mathrm{K}^{+}$ channels, inward (outward) rectification arises when the S4 segment in $\mathrm{K}^{+}$channels is located in the inner (outer) portion of the membrane. These two generic configurations can be thought of in terms of ranges for the parameter $b_{\mathrm{K}}$, namely, $b_{\mathrm{K}}<1 / 2$ for inward, and $b_{\mathrm{K}}>1 / 2$ for outward rectification.

In general, ion channels are typically formed by different subunits, that may combine in different ways, resulting in structural changes that may restrict the flow of ions through them, causing rectification. For instance, non-NMDA glutamatergic receptors that can be activated by kainic acid and $\alpha$-amino-3-hydroxy5-methyl-4-isoxazole propionic acid (AMPA) conduct $\mathrm{Na}^{+}$, $\mathrm{K}^{+}$, and $\mathrm{Ca}^{2+}$, with different permeabilities depending on the subunits that form the receptor (Hollmann et al., 1991). The reason is that the specific combination of GluR subunits forming the receptor restrict ionic flow in different ways. In particular, the currents recorded in oocytes injected with combinations of GluR1 and GluR3 cRNA have different steady state amplitudes and show different levels of rectification (Figure 3).
Primary active transport. The Na-K ATPase is a primary active transporter that uses the energy from the hydrolysis of one molecule of ATP for the uphill transport of $\mathrm{Na}^{+}$and $\mathrm{K}^{+}$(De Weer et al., 1988). The kinetics of the Na-K ATPase can be assumed to translocate $3 \mathrm{Na}^{+}$ions outward and $2 \mathrm{~K}^{+}$ions inward $\left(\eta_{\mathrm{NaK}}=1\right)$ with a reversal potential $v_{\mathrm{NaK}}=v_{\mathrm{ATP}}+3 v_{\mathrm{Na}}-2 v_{\mathrm{K}}$ (see Table 1) in a single transport event (Chapman, 1973; Garrahan \& Glynn, 1967; Gadsby et al., 1985; Post \& Jolly, 1957). Importantly, the transport kinetics of the Na-K ATPase and by extension, the current, reverse for potentials smaller than $v_{\mathrm{NaK}}($ De Weer et al., 1988).

The current-voltage relationships recorded from Na-K ATPases in guinea pig ventricular cells are shaped as hyperbolic sines (Gadsby et al., 1985). Those currents would be fit with $b_{\mathrm{NaK}} \approx 1 / 2$, yielding currents of the form

$$
i_{\mathrm{NaK}}(v)=2 \mathrm{q} r_{\mathrm{NaK}} \sinh \left(\frac{v-v_{\mathrm{NaK}}}{2 v_{T}}\right) .
$$

The voltage-dependence of the Na-K ATPase currents is reported to show a plateau as $v$ increases past the reversal potential for the current, in response to steroids like strophandin (Nakao \& Gadsby, 1989). In such cases, the Na-K ATPase current can be assumed to be inwardly rectifying and fit with values of $b_{\mathrm{NaK}} \approx 0$, so that,

$$
i_{\mathrm{NaK}}(v)=\mathrm{q} r_{\mathrm{NaK}}\left[1-\exp \left(\frac{v_{\mathrm{ATP}}+3 v_{\mathrm{Na}}-2 v_{\mathrm{K}}-v}{v_{\mathrm{T}}}\right)\right],
$$

or alternatively,

$$
i_{\mathrm{NaK}}(v)=\mathrm{q} r_{\mathrm{NaK}}\left[1-\left(\frac{[\mathrm{Na}]_{0}}{[\mathrm{Na}]_{1}}\right)^{3}\left(\frac{[\mathrm{K}]_{1}}{[\mathrm{~K}]_{0}}\right)^{2} \exp \left(\frac{v_{\mathrm{ATP}}-v}{v_{\mathrm{T}}}\right)\right] .
$$

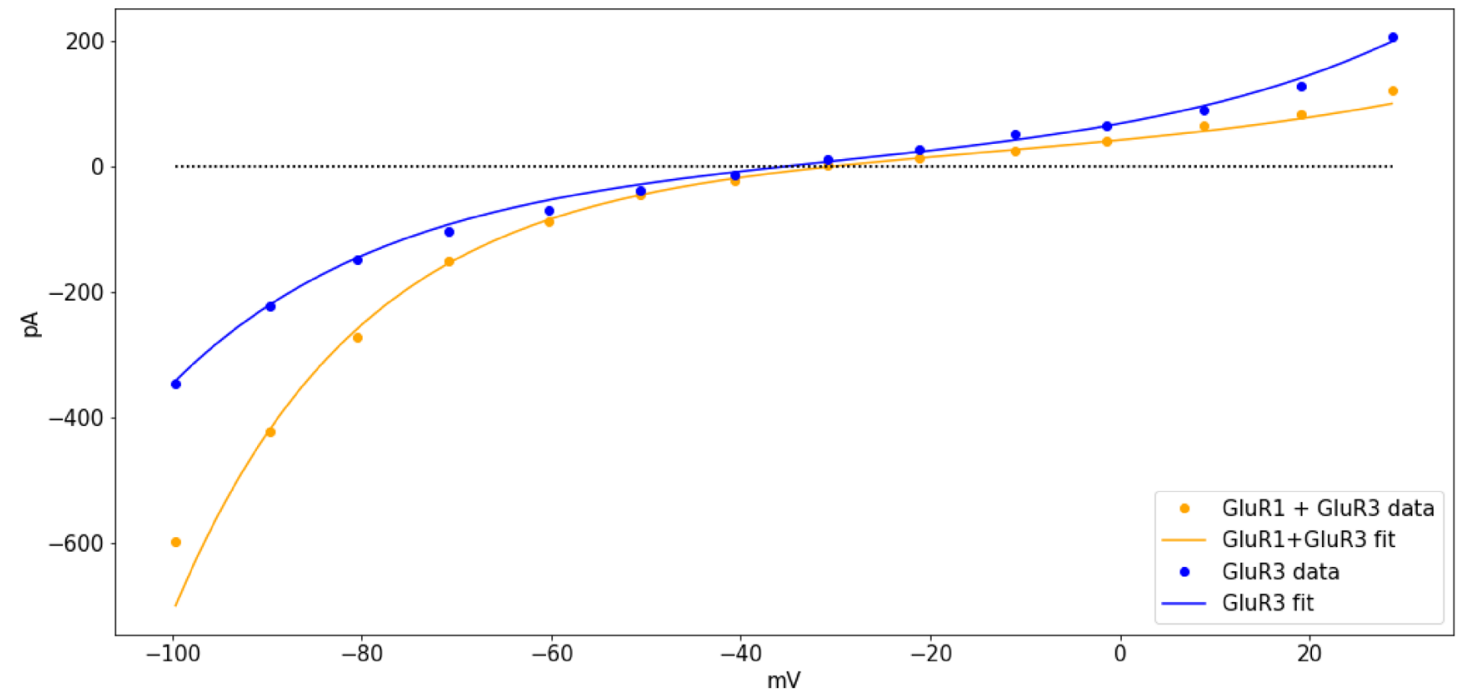

Figure 3. Currents recorded from oocytes injected with GluR3 cRNA (blue), or a combination of GluR1 and GluR3 cRNA (orange), in $\mathbf{C a}^{2+}$ ringer solution after activation by AMPA. The curves were fit with $\left(v_{o}, b, r q\right)=(-30,0.45,21)$, for $\mathrm{GluR3}$ and $\left(v_{o}, b, r q\right)=(-35,0.35,20)$, for GluR1+GluR3. The data was digitized from Figure 3B in the article by Hollmann et al. (1991), using the ginput function from the python module matplotlib (Hunter, 2007) - see Supplementary File 2. 
The rectification for the Na-K pump ATPase has also been reported to occur in small neurons of the dorsal root ganglion in rats (Hamada et al., 2003). The alternative expression (25) also explains qualitatively different behaviors of the $\mathrm{Na}-\mathrm{K}$ current as a function of the transmembrane concentrations of $\mathrm{Na}^{+}$and $\mathrm{K}^{+}$. For instance, if either $[\mathrm{Na}]_{1}$ or $[\mathrm{K}]_{0}$ increase and $v>v_{\mathrm{NaK}}$, then the amplitude of $i_{\mathrm{NaK}}$ would increase at a smaller rate of change in comparison to when $v<v_{\mathrm{NaK}}$, which grows exponentially in size. This is also in line with reports of non significant changes in the transport by $\mathrm{Na}-\mathrm{K}$ ATPases in response to elevated intracellular $\mathrm{Na}^{+}$during heart failure (Despa et al., 2002), in which the transmembrane potential is likely to be depolarized.

Secondary active transport.An example of a pump that mediates secondary active transport is the $\mathrm{Na}-\mathrm{Ca}$ exchanger, which takes $3 \mathrm{Na}^{+}$ions from the extracellular compartment in exchange for one intracellular $\mathrm{Ca}^{2+}$ ion in forward mode (Pitts, 1979; Reeves \& Hale, 1984). The reversal potential for the current is $v_{\mathrm{NaCa}}=2 v_{\mathrm{Ca}}-3 v_{\mathrm{Na}}$, with $\eta_{\mathrm{NaCa}}=1$. Assuming $b_{\mathrm{NaCa}}=1 / 2$, the Na-Ca current is

$$
i_{\mathrm{NaCa}}(v)=2 \mathrm{q} r_{\mathrm{NaCa}} \sinh \left(\frac{v-v_{\mathrm{NaCa}}}{2 v_{T}}\right)
$$

The driving force $v-v_{\mathrm{NaCa}}$ could reverse in sign with large enough increases in the intracellular concentration of $\mathrm{Ca}^{2+}$, or in the membrane potential. As a result, the current could have a dual contribution to the change in transmembrane potential, as predicted by some theoretical models of cardiac pacemaker activity (Rasmusson et al., 1990a; Rasmusson et al., 1990b).

Electrodiffusive transport. Consider transmembrane electrodiffusive transport of a single ionic type $x$, with $z_{x}$ and $v_{x}$ representing the valence and the Nernst potential for $x$-ions, respectively. In this case, the reversal potential satisfies

$$
v_{o}=n_{x}\left(c_{x}-d_{x}\right) z_{x} v_{x}=\eta_{x} v_{x}
$$

and the generic expression (16) can be rewritten as

$$
i_{x}(v)=\mathrm{q} \eta_{x} r_{x}\left\{\exp \left[\eta_{x} b_{x}\left(\frac{v-v_{x}}{v_{T}}\right)\right]-\exp \left[\eta_{x}\left(b_{x}-1\right)\left(\frac{v-v_{x}}{v_{T}}\right)\right]\right\} \text {. }
$$

In the absence of rectification $\left(b_{x}=0.5\right)$,

$$
i_{x}(v)=2 \mathrm{q} \eta_{x} r_{x} \sinh \left(\eta_{x} \frac{v-v_{x}}{2 v_{T}}\right) .
$$

For calcium channels,

$$
i_{\mathrm{Ca}}(v)=4 \mathrm{q} r_{\mathrm{Ca}} \sinh \left(\frac{v-v_{\mathrm{Ca}}}{v_{T}}\right) .
$$

See Jacquez \& Schultz (1974); Pickard (1969) Table 1 for other examples.

The applicability of the general formulations described above is illustrated next with models of cardiac and neuronal membrane potential.

\section{Transmembrane potential dynamics}

To show the application of the formulations discussed earlier, let us build a generic model of transmembrane potential dynamics with currents generated by $N$ different electrogenic transport mechanisms. For simplification purposes, consider only one such mechanism, labeled as $l$, with $p_{l} N_{l}$ active sites, where $N_{l}$ is the number of membrane sites where the $l$ th transport mechanism is found, and $p_{l}$ is the proportion of active sites (might be voltage or ligand dependent). Then the total current mediated by the $l$ th mechanism in a patch of membrane can be written as $\bar{a}_{l} p_{l} \varphi_{l}(v)$ with $\bar{a}_{l}=\mathrm{q} N_{l} r_{l}\left(\right.$ in $\left.\mathrm{pA} / \mu \mathrm{m}^{2}\right)$, and

$$
\varphi_{l}(v)=\exp \left[b_{l}\left(\frac{\eta_{l} v-v_{l}}{v_{\mathrm{T}}}\right)\right]-\exp \left[\left(b_{l}-1\right)\left(\frac{\eta_{l} v-v_{l}}{v_{\mathrm{T}}}\right)\right],
$$

where $v_{l} / \eta_{l}$ is the reversal potential for the $l$ th current, $l \in\{1, \ldots, N\}$. There is experimental evidence for some ion channels that supports the replacement of $\bar{a}_{l}$ as a constant (Nonner \& Eisenberg, 1998). The time-dependent change in transmembrane potential can written as

$$
\partial_{t} v=-\sum_{l=1}^{N} a_{l} p_{l} \varphi_{l}(v)
$$

with $v$ is in $\mathrm{mV}$ and $a_{l}=\bar{a}_{l} / C_{M}$ in $\mathrm{mV} / \mathrm{mS}(\mathrm{pA} / \mathrm{pF})$ represents the current amplitude for the $l$ th transport mechanism, normalized by the membrane capacitance, for $l \in(1, \ldots, N)$. Only electrogenic transport mechanisms are included.

\section{Cardiac pacemaking in the sinoatrial node}

The pacemaking dynamics of cells in the rabbit sinoanatrial node (Figure 4) can be modeled using low dimensional dynamical systems based on the assumption that $v$ changes as a function of $\mathrm{K}^{+}, \mathrm{Ca}^{2+}$, and some $\mathrm{Na}^{+}$transmembrane transport, (Herrera-Valdez \& Lega, 2011; Herrera-Valdez, 2014). Transmembrane currents are assumed to be mediated by a combination of channel-mediated electrodiffusion and pumping mechanisms. Explicitly, $\mathrm{Ca}^{2+}$ transport is mediated by L-type $\mathrm{Ca}_{v 13}$ channels (Mangoni et al., 2003) and $\mathrm{Na}^{+}-\mathrm{Ca}^{2+}$ exchangers (Sanders et al., 2006). $\mathrm{K}^{+}$transport is mediated by delayedrectifier voltage-activated channels (Shibasaki, 1987), and $\mathrm{Na}^{+}-\mathrm{K}^{+}$ATPases (Herrera-Valdez \& Lega, 2011; HerreraValdez, 2014). In this model, the activation for the L-type $\mathrm{Ca}^{2+}$ channels is fast, and assumed to be at steady state (Herrera-Valdez \& Lega, 2011). The proportion of activated $\mathrm{K}^{+}$channels and the proportion of inactivated $\mathrm{Ca}^{2+}$ channels are both represented by a variable $w$ (Av-Ron et al., 1991; Herrera-Valdez \& Lega, 2011). The activation phase of currents recorded in voltage-clamp experiments often displays sigmoidal time courses (Covarrubias et al., 1991; Hodgkin \& Huxley, 1952; Tsunoda \& Salkoff, 1995). Therefore, the activation dynamics represented by $w$ are described by solutions to equations of the form

$$
\partial_{t} w=w\left[F_{w}(v)-w\right] R_{w}(v) .
$$

where $F_{w}$ and $R_{w}$ represent the voltage-dependent steady state and rate $(1 / \mathrm{ms})$ for the opening of $\mathrm{Kd}$ channels (Willms et al., 1999). The steady state for the activation of voltage-dependent channels is described by the function 

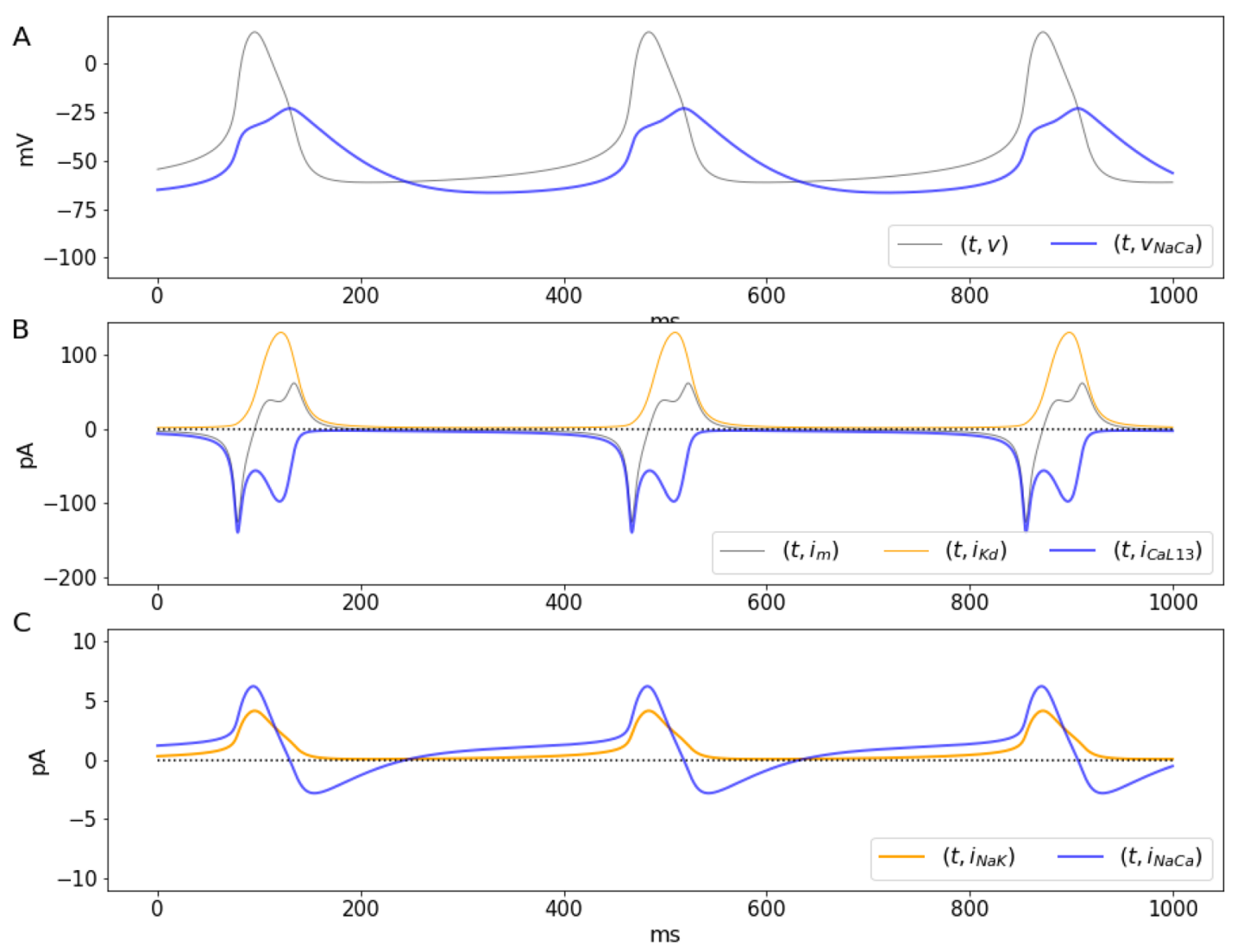

Figure 4. Central sinoatrial node pacemaking dynamics using the system (39)-(34). A. Transmembrane potential and the reversal potential $v_{\mathrm{NaCa}}$ as a function of time. B,C. Dynamics of large currents and small currents, respectively.

$$
F_{u}(v)=\frac{\exp \left(g_{u} \frac{v-v_{u}}{v_{\mathrm{T}}}\right)}{1+\exp \left(g_{u} \frac{v-v_{u}}{v_{\mathrm{T}}}\right)}, \quad u \in\{m, w\},
$$

which has a graph with increasing sigmoidal shape as a function of $v$. The parameters $g_{u}$ and $v_{u}$ control the steepness and the half-activation potential, for $u \in\{m, w\}$. The activation rate for $\mathrm{K}^{+}$channels is a voltage-dependent function of the form

$$
R_{w}(v)=r_{w}\left[\exp \left(b_{w} g_{w} \frac{v-v_{w}}{v_{\mathrm{T}}}\right)+\exp \left(\left(b_{w}-1\right) g_{w} \frac{v-v_{w}}{v_{\mathrm{T}}}\right)\right] \text {. }
$$

where $b_{w}$ represents a bias in the conformational change for activation. The function $R_{w}$ has the shape of a hyperbolic cosine when $b_{w}$ is $1 / 2$. The transmembrane (normalized) currents are given by

$$
\begin{aligned}
J_{\mathrm{NaK}}(v) & =a_{\mathrm{NaK}} \varphi_{\mathrm{NaK}}(v), \\
J_{\mathrm{NaCa}}(v, c) & =a_{\mathrm{NaCa}} \varphi_{\mathrm{NaCa}}(v, c), \\
J_{\mathrm{KD}}(v, w) & =a_{\mathrm{KD}} w \varphi_{\mathrm{KD}}(v), \\
J_{\mathrm{CaL}}(v, w, c) & =a_{\mathrm{Ca}}(1-w) F_{m}(v) \varphi_{\mathrm{Ca}}(v, c),
\end{aligned}
$$

where $c$ represents the intracellular $\mathrm{Ca}^{2+}$ concentration, and $\varphi_{x}$ is a difference of exponential functions as defined above, with $x \in\{\mathrm{NaK}, \mathrm{NaCa}, \mathrm{KD}, \mathrm{CaL}\}$. The temporal evolution for $v$ is then described by

$$
\partial_{t} v=-J_{\mathrm{NaK}}(v)-J_{\mathrm{NaCa}}(v, c)-J_{\mathrm{CaL}}(v, w, c)-J_{\mathrm{KD}}(v, w) .
$$

During pacemaking the concentrations of $\mathrm{Na}^{+}$and $\mathrm{K}^{+}$ across the membrane are assumed to change negligibly, but the $\mathrm{Ca}^{2+}$ concentration does change at least 10-fold (Herrera-Valdez \& Lega, 2011; Rasmusson et al., 1990a; Rasmusson et al., 1990b). Therefore, the system includes an equation for the dynamics for $c$ in which $c$ converges to a steady state $c_{\infty}$ in the absence of $\mathrm{Ca}^{2+}$ fluxes, and increases proportionally to the total transport of $\mathrm{Ca}^{2+}$ ions via L-type channels and $\mathrm{Na}^{+}-\mathrm{Ca}^{2+}$ exchangers (Figure 4). Explicitly,

$$
\partial_{t} c=r_{c}\left(c_{\infty}-c\right)-k_{c}\left[J_{\mathrm{CaL}}(v, w, c)-J_{\mathrm{NaCa}}(v, c)\right],
$$

where $k_{c}(\mu \mathrm{M} / \mathrm{mV})$ represents the impact of the transmembrane $\mathrm{Ca}^{2+}$ fluxes on the free intracellular $\mathrm{Ca}^{2+}$ concentration. The minus sign in front of $k_{c}$ accounts for the fact that the sign of the $J_{\mathrm{CaL}}$ is negative. The sign in front of $J_{\mathrm{NaCa}}$ is because the forward flux of $\mathrm{Ca}^{2+}$ mediated by the $\mathrm{Na}-\mathrm{Ca}$ exchanger is opposite to that of electrodiffusive $\mathrm{Ca}^{2+}$.

The solutions of Equation (32)-Equation (40) with parameters as in Table 2 reproduce important features of the membrane dynamics observed in the rabbit's central sinoatrial node, 
Table 2. Parameters for the cardiac SAN pacemaker model. The amplitudes $a_{l}$ can be thought of as $\bar{a}_{l} / C_{M}$ where $C_{M}$ is a constant that represents the rate of change in charge around the membrane as a function of $v$, and $l \in\{\mathrm{Ca} L, \mathrm{~K}, \mathrm{NaK}, \mathrm{NaCa}\}$.

\begin{tabular}{|c|c|c|c|}
\hline Parameter & Value & Units & Description \\
\hline$C_{M}$ & 30 & $\mathrm{pF}$ & Membrane capacitance \\
\hline $\bar{a}_{\mathrm{Ca}}$ & 1 & $\mathrm{pA}$ & $\begin{array}{l}\text { Maximum amplitude for the L-type } \mathrm{Ca}^{2+} \\
\text { current }\end{array}$ \\
\hline $\bar{a}_{\mathrm{K}}$ & 700 & $\mathrm{pA}$ & Maximum amplitude for the $\mathrm{K}^{+}$current \\
\hline $\bar{a}_{\mathrm{NaK}}$ & 1 & $\mathrm{pA}$ & Maximum amplitude for the $\mathrm{Na}^{+}-\mathrm{K}^{+}$current \\
\hline $\bar{a}_{\mathrm{NaCa}}$ & 2.5 & $\mathrm{pA}$ & $\begin{array}{l}\text { Maximum amplitude for the } \mathrm{Na}^{+}-\mathrm{Ca}^{2+} \\
\text { current }\end{array}$ \\
\hline$a_{\mathrm{Ca}}=\bar{a}_{\mathrm{Ca}} / C_{M}$ & 0.0333 & $\mathrm{pA} / \mathrm{pF}$ & $\begin{array}{l}\text { Maximum amplitude for the L-type } \mathrm{Ca}^{2+} \\
\text { current }\end{array}$ \\
\hline $\bar{a}_{\mathrm{K}}=\bar{a}_{\mathrm{K}} / C_{M}$ & 23.3333 & $\mathrm{pA} / \mathrm{pF}$ & Maximum amplitude for the $\mathrm{K}^{+}$current \\
\hline $\bar{a}_{\mathrm{NaK}}=\bar{a}_{\mathrm{NaK}} / C_{M}$ & 0.03333 & $\mathrm{pA} / \mathrm{pF}$ & Maximum amplitude for the $\mathrm{Na}^{+}-\mathrm{K}^{+}$current \\
\hline $\bar{a}_{\mathrm{NaCa}}=\bar{a}_{\mathrm{NaCa}} / C_{M}$ & 0.1 & $\mathrm{pA} / \mathrm{pF}$ & $\begin{array}{l}\text { Maximum amplitude for the } \mathrm{Na}^{+}-\mathrm{Ca}^{2+} \\
\text { current }\end{array}$ \\
\hline$V_{\text {ATP }}$ & -420 & $\mathrm{mV}$ & Potential ATP hydrolysis \\
\hline$V_{\mathrm{Na}}$ & 60 & $\mathrm{mV}$ & Nernst potential for $\mathrm{Na}^{+}$ \\
\hline$v_{\mathrm{k}}$ & -89 & $\mathrm{mV}$ & Nernst potential for $\mathrm{K}^{+}$ \\
\hline$v_{\mathrm{NaK}}=3 v_{\mathrm{Na}}-2 v_{\mathrm{K}}+v_{\text {ATP }}$ & -62 & $\mathrm{mV}$ & $\begin{array}{l}\text { Reversal potential for the for } \mathrm{Na}^{+}-\mathrm{K}^{+} \text {ATPase } \\
\text { current }\end{array}$ \\
\hline$v_{\mathrm{NaCa}}=2 v_{\mathrm{Ca}}-3 v_{\mathrm{Na}}$ & - & $\mathrm{mV}$ & $\begin{array}{l}\text { Reversal potential for the for } \mathrm{Na}^{+}-\mathrm{Ca}^{2+} \\
\text { current }\left(v_{\mathrm{Ca}} \text { depends continuously on }[\mathrm{Ca}]_{i}\right)\end{array}$ \\
\hline$v_{m+3}$ & -18 & $\mathrm{mV}$ & $\begin{array}{l}\text { Half-activation potential for } \mathrm{Ca}_{v 13} \text { L-type } \\
\mathrm{Ca}^{2+} \text {-current }\end{array}$ \\
\hline$v_{w}$ & 0 & $\mathrm{mV}$ & $\begin{array}{l}\text { Half-activation potential for the transient } \\
\mathrm{K}^{+} \text {-current }\end{array}$ \\
\hline$g_{m 13}$ & 4 & - & $\begin{array}{l}\text { Activation slope factor for the } \mathrm{Ca}_{v 13} \mathrm{~L} \text {-type } \\
\mathrm{Ca}^{2+} \text {-current }\end{array}$ \\
\hline$g_{w}$ & 3 & - & Activation slope factor for the $\mathrm{K}^{+}$-current \\
\hline$r_{w}$ & 0.05 & $\mathrm{~s}^{-1}$ & Activation rate for the cardiocyte $\mathrm{K}^{+}$-current \\
\hline$b_{w}$ & 0.35 & - & Activation slope factor for the $\mathrm{K}^{+}$-current \\
\hline$b_{\mathrm{Nak}}$ & 0.5 & - & Non-rectification bias for the $\mathrm{Na}^{+}-\mathrm{K}^{+}$-current \\
\hline$b_{k}$ & 0.5 & - & Rectification for the transient $\mathrm{K}^{+}$-current \\
\hline$b_{\mathrm{Na}}$ & 0.5 & - & $\begin{array}{l}\text { Non-rectification bias for the transient } \\
\mathrm{Na}^{+} \text {-current }\end{array}$ \\
\hline$b_{\mathrm{Ca}}$ & 0.5 & - & $\begin{array}{l}\text { Non-rectification bias for the } \mathrm{Ca}_{v 13} \mathrm{~L} \text {-type } \\
\mathrm{Ca}^{2+} \text {-current }\end{array}$ \\
\hline$C_{\infty}$ & 0.1 & $\mu \mathrm{M}$ & $\begin{array}{l}\text { Minimal (resting) intracellular } \mathrm{Ca}^{2+}- \\
\text { concentration }\end{array}$ \\
\hline$r_{c}$ & 0.02 & $\mathrm{~ms}^{-1}$ & $\mathrm{Ca}^{2+}$ removal rate \\
\hline$k_{c}$ & 0.00554 & - & $\begin{array}{l}\text { Conversion factor between } \mathrm{Ca}^{2+} \text { current } \\
\text { and intracellular } \mathrm{Ca}^{2+} \text { concentration }\end{array}$ \\
\hline
\end{tabular}

including the period ( $c a .400 \mathrm{~ms}$ ), amplitude ( $c a .70 \mathrm{mV}$ ), and maximum $\partial_{t} v(<10 \mathrm{~V} / \mathrm{s})$ of the action potentials (Zhang et al., 2000).

The solutions of the system show a number of interesting features related to ionic fluxes. First, the Na-Ca current reverses when $v=v_{\mathrm{NaCa}}$ (Figure $4 \mathrm{~A}$, blue line). During the initial depolarization and until the maximum downstroke rate, approximately, $v_{\mathrm{NaCa}}<v$, which means $J_{\mathrm{NaCa}}>0$, so that $\mathrm{Ca}^{2+}$ extrusion by the $\mathrm{Na}-\mathrm{Ca}$ exchanger occurs only for a brief period of time during the downstroke and also after each action potential (Figure 4C, blue line). Second, as previously reported in different studies involving spiking dynamics, the time course of the $\mathrm{Ca}^{2+}$ current shows a partial inactivation with a double peak 
(Figure 4B, blue line) around a local minimum (Carter \& Bean, 2009; Rasmusson et al., 1990a; Rasmusson et al., 1990b), and in agreement with data from voltage-clamp experiments (Mangoni et al., 2006). A number of models have made attempts to reproduce the double activation by making extra assumptions about gating (Rasmusson et al., 1990a; Rasmusson et al., 1990b). For instance, some models include a second activation variable, or the multiple terms in the steady state gating, or in the time constant for activation or inactivation. However, the explanation for the double peak can be much simpler. The calcium current $J_{\mathrm{CaL}}$ is a negative-valued, non monotonic function for $v<v_{\mathrm{Ca}}$, which can be thought of as a product of a amplitude term that includes gating and the function $\varphi_{\mathrm{CaL}}$. The normalized current $J_{\mathrm{CaL}}$ has a local minimum (maximum current amplitude) around $-10 \mathrm{mV}$ (Figure 4B, blue line and Figure 5A, blue line), after which the current decreases, reaching a local maximum as the total current passes through zero, at the peak of the action potential around $10 \mathrm{mV}$, (Figure $4 \mathrm{~B}$, where $\partial_{t} v=0$ ). The first peak for the $\mathrm{Ca}^{2+}$ current occurs when $v$ reaches the maximum depolarization rate (Figure 5B). As $v$ increases (e.g. upstroke of the action potential). The second peak for the current occurs as the membrane potential decreases, and passes again through the region where the maximal current occurs (local minimum for $J_{C a}$ ). The two local minima for $J_{\mathrm{CaL}}$ represent peaks in the $\mathrm{Ca}^{2+}$ current that have different amplitudes due the difference in the time course of $v$ during the upstroke and the downstroke of the action potential (Figure 5A, blue line, and Figure 5B, where $\partial_{t} v=0$ ). It is important to remark that the dual role played by $w$ is not the cause of the double activation. This is illustrated by analyzing the behavior of a non-inactivating $J_{\mathrm{CaL}}$ without the inactivation component, (Figure 5A, gray line). The double activation can also be observed in models in which the activation of $\mathrm{K}^{+}$channels and the inactivation of $\mathrm{Ca}^{2+}$ or $\mathrm{Na}^{+}$channels are represented by different variables (Rasmusson et al., 1990a) and in dynamic voltage clamp experiments on neurons in which there are transient and persistent sodium channels (Carter \& Bean, 2009).
The double peak in the $\mathrm{Ca}^{2+}$ current is reflected in the intracellular $\mathrm{Ca}^{2+}$ concentration (Figure 6, gray line), and by extension, on the Nernst potential for $\mathrm{Ca}^{2+}$ (Figure 6, blue line), which display two increasing phases and two decreasing phases, respectively. The first and faster phase in both cases occur during the initial activation of the L-type channels. The second phase occurs during the downstroke, as second peak of the $\mathrm{Ca}^{2+}$ current occurs. As a consequence, the reversal potential for the Na-Ca exchanger, $v_{\mathrm{NaCa}}=3 v_{\mathrm{Na}}-2 v_{\mathrm{Ca}}$ (Figure 6, orange line) also has two phases, this time increasing. Increasing the intracellular $\mathrm{Ca}^{2+}$ (Figure 6, gray line) concentration decreases the Nernst potential for $\mathrm{Ca}^{2+}$, and viceversa. By extension, the reversal potential for the $\mathrm{Na}-\mathrm{Ca}$ exchanger, $v_{\mathrm{NaCa}}=3 v_{\mathrm{Na}}-2 v_{\mathrm{Ca}}$ becomes larger when $c$ increases. $\mathrm{Ca}^{2+}$ enters the cell in exchange for $\mathrm{Na}^{+}$that moves out when $v>v_{\mathrm{NaCa}}$, during most of the increasing phase and the initial depolarization phase of the action potential (blue lines in Figure 4A and C, and Figure 6).

\section{Discussion}

A generic, macroscopic model for transmembrane fluxes has been derived by directly calculating the work required to transport molecules across the membrane. The derivation is based on a general thermodynamic scheme that takes into account the rate, stoichiometry, and the direction in which the molecules are transported across the membrane. These biophysical parameters are then combined to write expressions for directional fluxes based on van’t Hoff (1884) and Arrhenius (1889) formulations, weighted as in the Butler/Erdey-Gruz/Volmer equation (Butler, 1924; Erdey-Grúz \& Volmer, 1930). The result is a general description (Equation 16) of the transmembrane molecular flux as a difference of exponential functions, that describes the transport dynamics in the "forward" and "backward" directions, relative to a source compartment. The two exponential functions depend on a common expression involving the transmembrane concentrations of the molecules being transported, and possibly the transmembrane potential when transport is electrogenic.
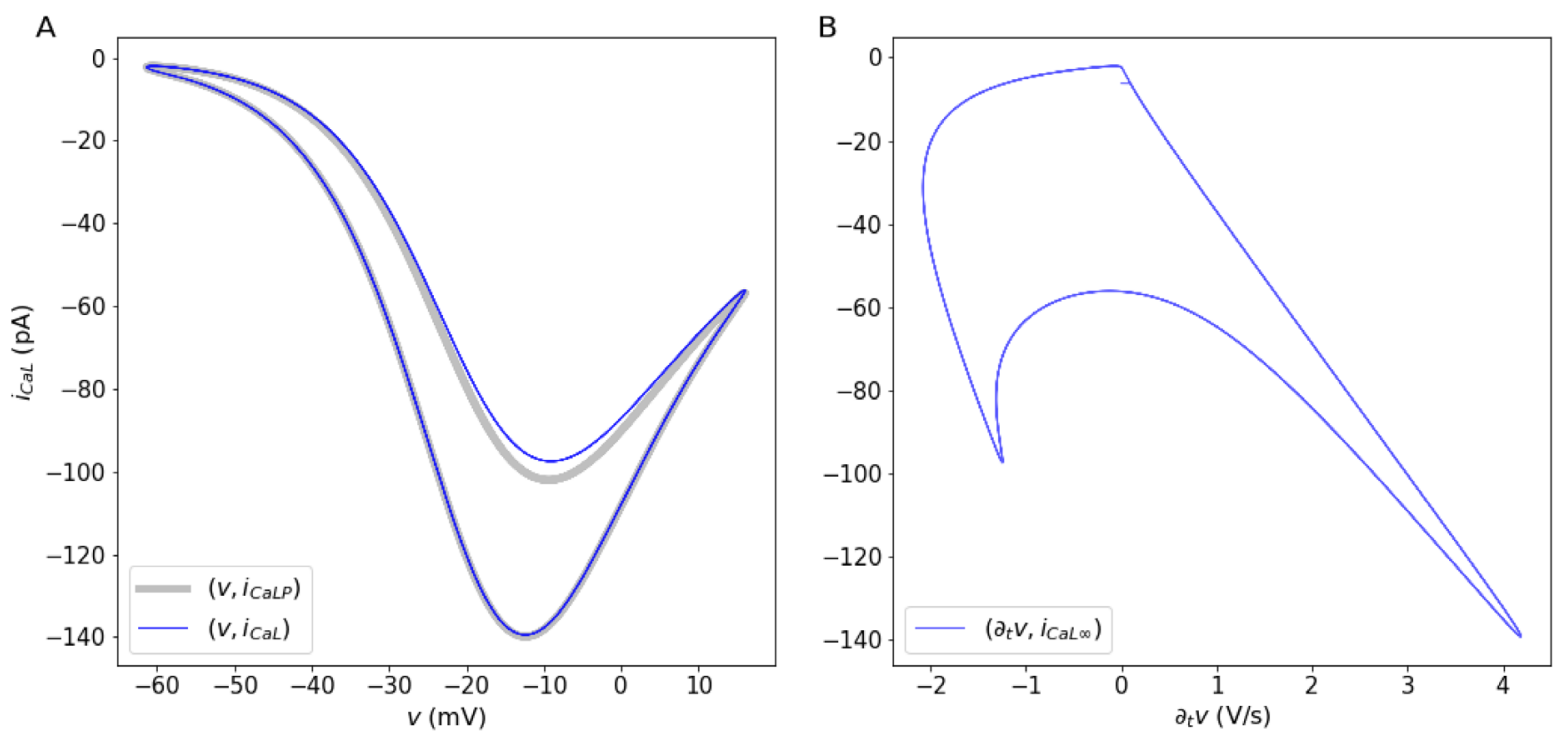

Figure 5. Dynamics of the calcium current and double activation. A. Behavior of the inactivating L-type Ca ${ }^{2+}$ current with respect to the transmembrane potential (blue line) and a non-inactivating current (gray line), and (B) with respect to the time-dependent change in $v$. 


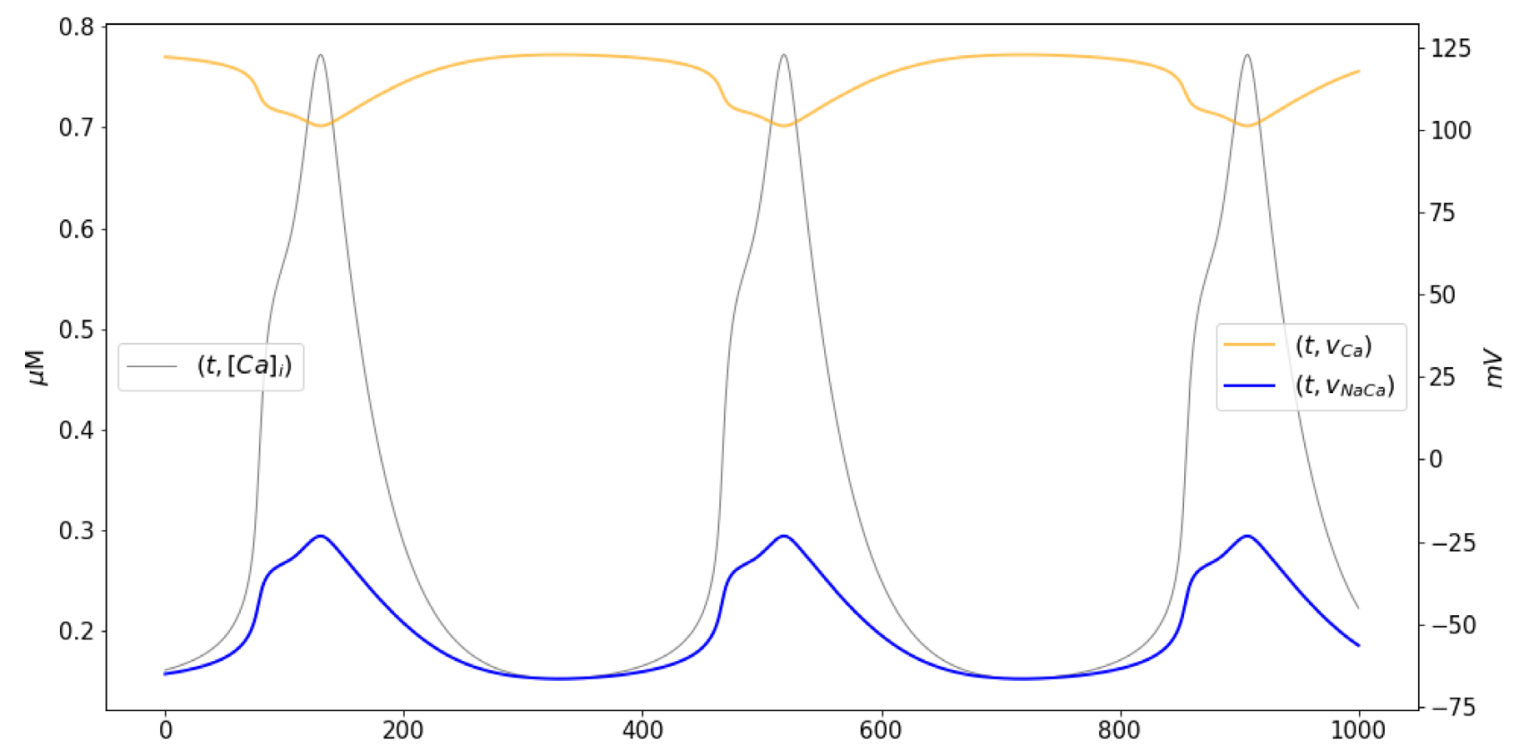

Figure 6. Calcium dynamics during pacemaking. Time courses of the intracellular calcium concentration (gray, left axis), the Nernst potential for $\mathrm{Ca}^{2+}$ (orange, right axis), and the reversal potential for the $\mathrm{Na}-\mathrm{Ca}$ exchanger (blue, right axis).

Rectification, an asymmetry in the flow, is typically modeled modifying the dynamics of the gating variables of the current. The general formulas for transmembrane transport include a bias term $b$ that controls the relative contribution of inward and outward components the transport. Hence, different types of rectification can be described by favoring one of the directions for transport, conceptually in line with the "anomalous rectification" originally reported by Katz (1949) for $\mathrm{K}^{+}$in muscle cells. The bias term is not part of any gating mechanism. Instead, it represents the asymmetry in bidirectional flux Based on the work of Riedelsberger et al. (2015), the inward (outward, respectively) rectification in $\mathrm{K}^{+}$channels occurs when the fourth transmembrane segment of the channel (S4) is located closer to the intracellular (extracellular) portion of the membrane in its open configuration. There are other reports that show that asymmetries in bidirectional transport occur as a consequence of changes in the three dimensional structure of the protein mediating the transport (Halliday \& Resnick, 1981; Quistgaard et al., 2013). Therefore, the rectification term can be thought of as representing a structural component of the transmembrane protein through which molecules move (Figure 2). Outward rectification in $\mathrm{K}^{+}$channels can be explained, for instance, by biasing the flux of $\mathrm{K}^{+}$the forward (outward) direction $\left(b_{\mathrm{K}}>1 / 2\right)$. Instead, inward rectification can be obtained by biasing the transport in the backward (inward) direction $\left(b_{\mathrm{K}}<1 / 2\right)$. It is important to remark that non-rectifying currents with $b=1 / 2$ are nonlinear functions of $\Delta G$, which shows that the nonlinearity of the current-voltage relationships is not the defining characteristic of rectification; as argued in some textbooks (see Kew \& Davies, 2010).

The formulation for transmembrane flux may be rewritten in different alternative forms that can be found throughout the literature (see Equation (13) and Equation (14), Goldman, 1943; Johnston et al., 1995). Of particular interest, the widely used conductance-based models for current from the seminal work of Hodgkin \& Huxley (1952) turn out to be linear approximations of the generic current described here (Herrera-Valdez, 2012; Herrera-Valdez, 2014). This explains why the Hodgkin \& Huxley (1952) model captures many of the defining features of action potential generation, in spite of modeling ionic currents as resistive. Another interesting case is that electrodiffusive transmembrane currents derived from the NernstPlanck equation (Nernst, 1888; Planck, 1890), turn out particular cases of the generic formulation presented here (see also Herrera-Valdez, 2014, for details). Examples include the constant field approximation (Clay et al., 2008; Hille, 1992; Johnston et al., 1995), the non-rectifying currents proposed by Endresen et al. (2000), and more general electrodiffusive currents that includes a bias term accounting for rectification (Herrera-Valdez, 2014; Johnston et al., 1995).

Possibly of interest to mathematicians working on bifurcation theory, a third order approximation (Equation (17)) resembling the Fitz-Hugh equations (FitzHugh, 1955; FitzHugh, 1961; Fitz-Hugh, 1966), can be used to construct models that give very close approximations to the full model, while keeping biophysical characteristics like rectification and the multiplicative interaction between the slow variable $w$ and the fast variable $v$. Further, the third order approximation opens the possibility of expanding on the analysis of dynamical systems based on these generic formulas to study normal forms and bifurcations. Another possible use of the third order approximations is in the construction of network models.

One question of interest because of its possible impact on the interpretation of results from existing modeling studies is how does the excitability and the resulting dynamics in a model of membrane dynamics change when using the thermodynamic transmembrane currents or their approximations? The question has been addressed in a study in which two simple neuronal models with currents mediated by $\mathrm{Na}^{+}$and $\mathrm{K}^{+}$, each equipped with the same biophysical gating properties and the same relative contributions for the currents, but one with currents as in 
Equation (19), the other with conductance-based currents. The two models display a number of qualitative and quantitative differences worth considering while making the choice of a model in theoretical studies (Herrera-Valdez, 2012). For a start, the two models are not topologically equivalent across many ratios of the relative contributions of $\mathrm{K}^{+}$and $\mathrm{Na}^{+}$channels (Herrera-Valdez, 2012); as would be expected by the fact that conductance-based formulations are only linear approximations of the generic currents. One of the most notable differences is the contribution of the nonlinear, high order terms from Equation (16), which results in more realistic upstrokes for action potentials and an overall increased excitability; in this case characterized in terms of the minimum sustained current necessary to produce at least one action potential. The increased excitability of the membrane is due, in part, to the large, exponential contribution of the open $\mathrm{Na}^{+}$and $\mathrm{Ca}^{2+}$ channels, but not the $\mathrm{K}^{+}$channels, to the change in the transmembrane potential near rest. The time course of the $\mathrm{Na}^{+}$current during the beginning of the action potential with the generic model is much sharper than that of the conductance-based formulation, resulting in a faster upstroke of the action potential; and in better agreement with observations in cortex and other tissues (Naundorf et al., 2006). It is important to remark that the sharper increase in the change of the membrane potential is a consequence of the nonlinear driving force terms of the current (the flux term in the generic formulation) and not in the activation dynamics for the transient $\mathrm{Na}^{+}$current.

The generic formulation for both passive and active transmembrane transport can be thought of as a tool that facilitates the construction and analysis of models of membrane potential dynamics. The generality and versatility of the thermodynamic transmembrane transport formulations is illustrated with a model of the dynamics of cardiac pacemaking (equations (39)-(34)). Another example with a model for a fast spiking interneuron can be found in Supplementary File 1. The ion fluxes in the model are assumed to be mediated by two different types of voltage-gated channels and two different types of pumps, all represented with the same functional form (see DiFrancesco \& Noble (1985); Herrera-Valdez \& Lega (2011); Rasmusson et al. (1990b) for examples in which that is not the case).

One important advantage of the generic formulation is that it includes the possibility of explicitly estimating the number of channels or pumps mediating each of the transport mechanisms of interest. This has proven to be useful to study the relative contributions of different currents to the excitability of neurons (see Herrera-Valdez et al., 2013) and cardiocytes (Herrera-Valdez, 2014).

Another extension of possible interest is that of modelling the transmembrane transport between organelles and the cytosolic compartment, which can be done by directly replacing the difference $c_{s}-d_{s}$ in Equation (1) with 1 or -1 , accounting for the direction of transmembrane motion of molecules relative to the outer compartment. This and other generalizations enable the possibility of studying the interdependence between electrical excitability across tissues and animal species (Herrera-Valdez et al., 2013), and its cross-interactions with metabolism and other processes of physiological importance, all from a general theoretical framework with common formulations.

Implications for experimentalists. One of the main advantages of the generic expressions is that fits to ionic currents can be made straight from the voltage-clamp data without much effort, and without having to calculate conductances, which amounts to imposing the assumption that the current to voltage relationship is linear. Fits to experimental currents can then be directly put into equations describing the change in the membrane potential, and model membrane dynamics of interest without having to make many extra adjustments, as it is the case for most conductance-based models restricted to data.

The model for current in Equation (19) has been used to construct simplified models for the membrane dynamics of different cell types using experimental data. Examples include motor neurons in Drosophila melanogaster (Herrera-Valdez et al., 2013), pyramidal cells in the young and ageing hippocampus of rats (McKiernan et al., 2015), medium spiny neurons in the mouse striatum (Suárez et al., 2015), rabbit sinoatrial node cells (Herrera-Valdez, 2014), and other types of excitable cells (McKiernan \& Herrera-Valdez, 2012).

\section{Conclusions}

A generic model that describes physiological transmembrane transport of molecules has been derived by considering basic thermodynamical principles. The model unifies descriptions of transport mediated by channels and pumps, it can model biases in either one of the directions of flow, and it can be easily converted into a model for current in the case of electrogenic transport. As it is desirable in all models, the generic expressions can be thought of as extensions of some previous models. In particular, it is shown that the conductance-based model for current turns out to be a first order approximation of the generic formulation.

The expressions for current and molecular fluxes across the membrane based on the generic formulation can be used to build general models of transmembrane potential using a unified framework (Shou et al., 2015).

\section{Data availability}

All data underlying the results are available; two source data files are included with this article (Supplementary File 2).

\section{Grant information}

This work was supported by UNAM-PAPIIT IA208618.

The funders had no role in study design, data collection and analysis, decision to publish, or preparation of the manuscript.

\section{Acknowledgements}

The author wishes to thank Joceline Lega, Timothy Secomb, and Raphael Gruener at the University of Arizona; Jose Bargas-Diaz and Antonio Laville from the Cellular Physiology Institute at UNAM; and Erin C. McKiernan from the Physics Department at UNAM for all the time spent in discussions that helped to solidify and deepen the ideas presented in this paper. 


\section{Supplementary material}

Supplementary File 1: The Goldman constant field approximation from the general formulation.

Click here to access the data.

Supplementary File 2: CaPermeabilityKA-AMPA-GatedGluR_Hollman et al. (1991). Figure 3B GluR3 and GluR1+3.

Click here to access the data.

Adrian RH: Rectification in muscle membrane. Prog Biophys Mol Biol. 1969; 19(2): 339-369.

PubMed Abstract | Publisher Full Text

Aidley DJ: The Physiology of Excitable Cells. Cambridge University Press 4 edition, 1998. ISBN 0521574153,9780521574150.

Reference Source

Almers W, McCleskey EW: Non-selective conductance in calcium channels of frog muscle: calcium selectivity in a single-file pore. J Physiol. 1984; 353(1): 585-608.

PubMed Abstract | Publisher Full Text | Free Full Text

ARMSTRONG CM, BINSTOCK L: Anomalous rectification in the squid giant axon injected with tetraethylammonium chloride. $J$ Gen Physiol. 1965; 48(5): $859-872$

PubMed Abstract | Publisher Full Text | Free Full Text

Arrhenius S: Über die reaktionsgeschwindigkeit bei der inversion von rohrzucker durch säuren. Zeitschrift für physikalische Chemie. 1889; 4U(1): 226-248.

Publisher Full Text

Ashcroft FM: ATP-sensitive potassium channelopathies: focus on insulin secretion. J Clin Invest. 2005; 115(8): 2047-2058.

PubMed Abstract | Publisher Full Text | Free Full Text

Av-Ron E, Parnas H, Segel LA: A minimal biophysical model for an excitable and oscillatory neuron. Biol Cybern. 1991; 65(6): 487-500.

PubMed Abstract | Publisher Full Text

Barr L: Membrane potential profiles and the Goldman equation. J Theor Biol. 1965; 9(3): 351-356.

PubMed Abstract | Publisher Full Text

BENNETT HS: The concepts of membrane flow and membrane vesiculation as mechanisms for active transport and ion pumping. J Biophys Biochem Cytol.

1956; 2(4 Suppl): 99-103.

PubMed Abstract | Publisher Full Text | Free Full Text

Blaustein MP, Kao JPY, Matteson DR: Cellular physiology. Elsevier/Mosby, 2004. ISBN 0323013414

Reference Source

Blicher A, Heimburg T: Voltage-Gated Lipid Ion Channels. PLoS One. 2013; 8(6): e65707.

PubMed Abstract | Publisher Full Text | Free Full Text

Butler JAV: Studies in heterogeneous equilibria. Part II.- - the kinetic interpretation of the nernst theory of electromotive force. Trans Faraday Soc.

1924; 19: 729-733

Publisher Full Text

Carter BC, Bean BP: Sodium entry during action potentials of mammalian neurons: incomplete inactivation and reduced metabolic efficiency in fastspiking neurons. Neuron. 2009; 64(6): 898-909.

PubMed Abstract | Publisher Full Text | Free Full Text

Chapman JB: Letter: On the reversibility of the sodium pump in dialyzed squid axons. A method for determining the free energy of ATP breakdown? J Gen

Physiol. 1973; 62(5): 643-6.

PubMed Abstract | Publisher Full Text | Free Full Text

Clay JR, Paydarfar D, Forger DB: A simple modification of the Hodgkin and Huxley equations explains type 3 excitability in squid giant axons. $J R$ Soc Interface. 2008; 5(29): 1421-1428.

PubMed Abstract | Publisher Full Text | Free Full Text

COLE KS: Electrodiffusion models for the membrane of squid giant axon. Physiol Rev. 1965; 45(2): 340-79. ISSN 0031-9333.

PubMed Abstract | Publisher Full Text

Courant R, John F: Introduction to calculus and analysis I. Springer Science \& Business Media, 2012

Covarrubias M, Wei AA, Salkoff L: Shaker, Shal, Shab, and Shaw express independent $\mathbf{K}^{+}$current systems. Neuron. 1991; 7(5): 763-773.

PubMed Abstract | Publisher Full Text
De Weer P, Gadsby DC, Rakowski RF: Voltage dependence of the Na-K pump. Annu Rev Physiol. 1988; 50(1): 225-241.

PubMed Abstract | Publisher Full Text

Despa S, Islam MA, Weber CR, et al.: Intracellular $\mathrm{Na}^{+}$concentration is elevated in heart failure but $\mathrm{Na} / \mathrm{K}$ pump function is unchanged. Circulation. 2002; 105(21): 2543-2548

PubMed Abstract | Publisher Full Text

DiFrancesco D, Noble D: A model of cardiac electrical activity incorporating ionic pumps and concentration changes. Philos Trans $R$ Soc Lond B Biol SCi. 1985; 307(1133): 353-398.

PubMed Abstract | Publisher Full Text

Doyle DA, Morais Cabral J, Pfuetzner RA, et al.: The structure of the potassium channel: molecular basis of $\mathbf{K}^{+}$conduction and selectivity. Science. 1998; 280(5360): 69-77.

PubMed Abstract | Publisher Full Text

Endresen LP, Hall K, Høye JS, et al:: A theory for the membrane potential of living cells. Eur Biophys J. 2000; 29(2): 90-103.

PubMed Abstract | Publisher Full Text

Erdey-Grúz T, Volmer M: Zur theorie der wasserstoff überspannung. Zeitschrift für Physikalische Chemie. 1930; 150A(1): 203-213.

Publisher Full Text

Favre I, Moczydlowski E, Schild L: On the structural basis for ionic selectivity among $\mathrm{Na}^{+}, \mathrm{K}^{+}$, and $\mathrm{Ca}^{2+}$ in the voltage-gated sodium channel. Biophys $\mathrm{J} .1996$ 71(6): 3110-3125.

PubMed Abstract | Publisher Full Text | Free Full Text

Fitz-Hugh R: Mathematical models of excitation and propagation in nerve.

Publisher Unknown, 1966.

Reference Source

FitzHugh R: Impulses and Physiological States in Theoretical Models of Nerve Membrane. Biophys J. 1961; 1(6): 445-466.

PubMed Abstract | Publisher Full Text | Free Full Text

FitzHugh R: Mathematical models of threshold phenomena in the nerve membrane. Bull Math Biol. 1955; 17(4): 257-278.

Publisher Full Text

Gadsby DC, Kimura J, Noma A: Voltage dependence of $\mathrm{Na} / \mathrm{K}$ pump current in isolated heart cells. Nature. 1985; 315(6014): 63-65.

PubMed Abstract | Publisher Full Text

Gadsby DC: Ion channels versus ion pumps: the principal difference, in principle. Nat Rev Mol Cell Biol. 2009; 10(5): 344-352.

PubMed Abstract | Publisher Full Text | Free Full Text

Garrahan PJ, Glynn IM: The behaviour of the sodium pump in red cells in the absence of external potassium. J Physiol. 1967; 192(1): 159-174.

PubMed Abstract | Publisher Full Text | Free Full Text

Goldman DE: Potential, Impedance, and Rectification in Membranes. J Gen Physiol. 1943; 27(1): 37-60.

PubMed Abstract | Publisher Full Text | Free Full Text

Halliday D, Resnick R: Fundamentals of physics. John Wiley \& Sons, 1981. Reference Source

Hamada K, Matsuura $\mathrm{H}$, Sanada $\mathrm{M}$, et al:: Properties of the $\mathrm{Na}^{+} / \mathrm{K}^{+}$pump current in small neurons from adult rat dorsal root ganglia. $\mathrm{Br} \mathrm{J} \mathrm{Pharmacol.} \mathrm{2003;}$ 138(8): 1517-1527.

PubMed Abstract | Publisher Full Text | Free Full Text

Herrera-Valdez MA: Geometry and nonlinear dynamics underlying electrophysiological phenotypes in biophysical models of membrane potential. Dissertation. Ph.D. in Mathematics. University of Arizona. 2014 Herrera-Valdez MA: Membranes with the same ion channel populations but different excitabilities. PLoS One. 2012; 7(4): e34636. PubMed Abstract | Publisher Full Text | Free Full Text

Herrera-Valdez MA, Lega J: Reduced models for the pacemaker dynamics of cardiac cells. J Theor Biol. 2011; 270(1): 164-176.

PubMed Abstract | Publisher Full Text 
Herrera-Valdez MA, Lega J: Reduced models for the pacemaker dynamics of cardiac cells. J Theor Biol. 2011; 270(1): 164-176.

PubMed Abstract | Publisher Full Text

Herrera-Valdez MA, McKiernan EC, Berger SD, et al.: Relating ion channe expression, bifurcation structure, and diverse firing patterns in a model of an identified motor neuron. J Comput Neurosci. 2013; 34(2): 211-29.

PubMed Abstract | Publisher Full Text

Hille B: Ionic Channels of Excitable Membranes. Sinauer Associates, Sinauer Associates, Inc. Sunderland, Mass. 01375, 1992.

Reference Source

Hodgkin AL, Huxley AF: A quantitative description of membrane current and its application to conduction and excitation in nerve. J Physiol. 1952; 117(4): $500-544$.

PubMed Abstract | Publisher Full Text | Free Full Text

Hodgkin AL, Katz B: The effect of sodium ions on the electrical activity of giant axon of the squid. J Physiol. 1949; 108(1): 37-77.

PubMed Abstract | Publisher Full Text | Free Full Text

Hollmann M, Hartley M, Heinemann S: Ca2+ permeability of KA-AMPA--gated glutamate receptor channels depends on subunit composition. Science. 1991 252(5007): 851-853.

PubMed Abstract | Publisher Full Tex

Hunter JD: Matplotlib: A 2d graphics environment. Computing in Science \& Engineering. 2007; 9(3): 90-95.

Publisher Full Text

Jacquez JA, Schultz SG: A general relation between membrane potential, ion activities, and pump fluxes for symmetric cells in a steady state. Math Biosci. 1974; 20(1-2): 19-25.

Publisher Full Text

Jacquez JA: A general relation between membrane potential, ion activities, and pump fluxes for nonsymmetric cells in a steady state. Math Biosci. 1981; 53(1-2): 53-57.

Publisher Full Text

Johnston D, Wu SMS, Gray R: Foundations of cellular neurophysiology. MIT press Cambridge, MA, 1995. ISBN 0262100533

Reference Source

Katz B: Les constantes electriques de la membrane du muscle. Arch Sci Physiol. 1949; 3: 285-299.

Reference Source

Kell DB: On the functional proton current pathway of electron transport phosphorylation. An electrodic view. Biochim Biophys Acta. 1979; 549(1): 55-99. PubMed Abstract | Publisher Full Text

Kew JNC, Davies $\mathrm{CH}$ : Ion channels: from structure to function. Oxford University Press, USA, 2010.

Publisher Full Text

Läuger P: Ion transport through pores: a rate-theory analysis. Biochim Biophys Acta. 1973; 311(3): 423-441.

PubMed Abstract | Publisher Full Text

Lowe AG, Walmsley AR: The kinetics of glucose transport in human red blood cells. Biochim Biophys Acta. 1986; 857(2): 146-154.

PubMed Abstract | Publisher Full Text

Mangoni ME, Couette B, Bourinet E, et al:: Functional role of L-type $\mathrm{Ca}_{\mathbf{1}} \mathbf{1 . 3 \mathrm { Ca } ^ { 2 + }}$ channels in cardiac pacemaker activity. Proc Natl Acad Sci U S A. 2003; 100(9): 5543-5548.

PubMed Abstract | Publisher Full Text | Free Full Text

Mangoni ME, Couette B, Marger L, et al:: Voltage-dependent calcium channels and cardiac pacemaker activity: from ionic currents to genes. Prog Biophys $\mathrm{Mol}$ Biol. 2006; 90(1-3): 38-63.

PubMed Abstract | Publisher Full Tex

Marbán E: Cardiac channelopathies. Nature. 2002; 415(6868): 213-8.

PubMed Abstract | Publisher Full Text

McKiernan EC, Herrera-Valdez MA, Marrone DF: A biophysical, minimal model to explore age-related changes in ion channel gene expression and excitability in ca1 pyramidal cells. Society for Neurosciences Annual Meeting. Session 628 Learning and Memory: Aging III, Poster 628.10/AA45., 2015.

Reference Source

McKiernan EC, Herrera-Valdez MA: From spinal cord to hippocampus: links between bifurcation structure, ion channel expression, and firing patterns in variety of neuron types. BMC Neurosci. 2012; 13(Suppl 1): P121.

Publisher Full Text | Free Full Text

Mullins LJ: The generation of electric currents in cardiac fibers by $\mathrm{Na} / \mathrm{Ca}$ exchange. Am J Physiol. 1979; 236(3): C103-C110.

PubMed Abstract | Publisher Full Text

Nakao M, Gadsby DC: [Na] and [K] dependence of the $\mathrm{Na} / \mathrm{K}$ pump currentvoltage relationship in guinea pig ventricular myocytes. J Gen Physiol. 1989; 94(3): 539-565

PubMed Abstract | Publisher Full Text | Free Full Text

Naundorf $B$, Wolf $F$, Volgushev $M$ : Unique features of action potential initiation in cortical neurons. Nature. 2006; 440(7087): 1060-3.

PubMed Abstract | Publisher Full Text

Nernst W: Zur kinetik der in lösung befindlichen körper. Zeitschrift für

physikalische Chemie. 1888; 2(1): 613-637.

Publisher Full Text

Nonner W, Eisenberg R: Ion permeation and glutamate residues linked by
Poisson-Nernst-Planck theory in L-type calcium channels. Biophys J. 1998; 75(3): 1287-1305.

PubMed Abstract | Publisher Full Text | Free Full Text

Novák B, Tyson JJ: Design principles of biochemical oscillators. Nat Rev Mol Cell Biol. 2008; 9(12): 981-91.

PubMed Abstract | Publisher Full Text | Free Full Text

Pickard WF: A postulational approach to the problem of ion flux through membranes. Math Biosci. 1969; 4(1-2): 7-21.

Publisher Full Text

Pickard WF: Generalizations of the goldman-hodgkin-katz equation. Math Biosci. 1976; 30(1-2): 99-111.

Publisher Full Text

Pitts BJ: Stoichiometry of sodium-calcium exchange in cardiac sarcolemmal vesicles. Coupling to the sodium pump. J Biol Chem. 1979; 254(14): 6232-6235. PubMed Abstract

Planck M: Ueber die Potentialdifferenz zwischen zwei verdünnten Lösungen binärer Electrolyte. Annalen der Physik. 1890; 276(8): 561-576.

Publisher Full Text

Post RL, Jolly PC: The linkage of sodium, potassium, and ammonium active transport across the human erythrocyte membrane. Biochim Biophys Acta. 1957; 25(1): 118-128.

PubMed Abstract | Publisher Full Text

Quistgaard EM, Löw C, Moberg P, et al:: Structural basis for substrate transport in the GLUT-homology family of monosaccharide transporters. Nat Struct MOl Biol. 2013; 20(6): 766-8.

PubMed Abstract | Publisher Full Text

Rasmusson RL, Clark JW, Giles WR, et al:: A mathematical model of electrophysiological activity in a bullfrog atrial cell. Am J Physiol. 1990a; 259(2 Pt 2): H370-H389.

PubMed Abstract | Publisher Full Text

Rasmusson RL, Clark JW, Giles WR, et al:: A mathematical model of a bullfrog cardiac pacemaker cell. Am J Physiol. 1990b; 259(2 Pt 2): H352-H369.

PubMed Abstract | Publisher Full Text

Reeves JP, Hale CC: The stoichiometry of the cardiac sodium-calcium exchange system. J Biol Chem. 1984; 259(12): 7733-7739.

PubMed Abstract

Riedelsberger J, Dreyer I, Gonzalez W: Outward Rectification of Voltage-Gated $\mathrm{K}^{+}$Channels Evolved at Least Twice in Life History. PLoS One. 2015; 10(9): e0137600.

PubMed Abstract | Publisher Full Text | Free Full Text

Rosenberg T, Wilbrandt W: The kinetics of membrane transports involving chemical reactions. Exp Cell Res. 1955; 9(1): 49-67.

PubMed Abstract | Publisher Full Text

Sanders L, Rakovic S, Lowe M, et al:: Fundamental importance of $\mathrm{Na}^{+}-\mathrm{Ca} 2$ exchange for the pacemaking mechanism in guinea-pig sino-atrial node. J Physiol. 2006; 571(Pt 3): 639-49.

PubMed Abstract | Publisher Full Text | Free Full Text

Sen AK, Widdas WF: Determination of the temperature and $\mathrm{pH}$ dependence of glucose transfer across the human erythrocyte membrane measured by glucose exit. J Physiol. 1962; 160(3): 392-403.

PubMed Abstract | Publisher Full Text | Free Full Text

Shibasaki T: Conductance and kinetics of delayed rectifier potassium channels in nodal cells of the rabbit heart. $J$ Physiol. 1987; 387(1): 227-50.

PubMed Abstract | Publisher Full Text | Free Full Text

Shou W, Bergstrom CT, Chakraborty AK, et al.: Theory, models and biology. eLife. 2015; 4: e07158.

PubMed Abstract | Publisher Full Text | Free Full Text

Skou JC: Enzymatic basis for active transport of $\mathrm{Na}^{+}$and $\mathrm{K}^{+}$across cell membrane. Physiol Rev. 1965; 45(3): 596-618.

PubMed Abstract | Publisher Full Text

Spivak M: Calculus on manifolds: a modern approach to classical theorems of advanced calculus. CRC Press, 2018.

Reference Source

Starace DM, Stefani E, Bezanilla F. Voltage-dependent proton transport by the voltage sensor of the Shaker K+ channel. Neuron. 1997; 19(6):

$1319-1327$.

PubMed Abstract | Publisher Full Text

Stein WD, Litman T: Channels, carriers, and pumps: an introduction to membrane transport. Elsevier, 2014

Publisher Full Text

Stevens CF, Tsien RW: Ion permeation through membrane channels. Raven Press, 1979; 3.

Suárez P, Herrera-Valdez MA, Bargas J, et al:: Un modelo biofísico de neurona estriatales de proyección que toma en cuenta la contribución de canales de calcio cav3. Escuela de Otoño de Biomatemáticas, Jalapa, Veracruz, México. 2015. Reference Source

Tanford C: Equilibrium state of ATP-driven ion pumps in relation to physiological ion concentration gradients. J Gen Physiol. 1981; 77(2): 223-229. PubMed Abstract | Publisher Full Text | Free Full Text

Tsunoda S, Salkoff L: The major delayed rectifier in both Drosophila neurons and muscle is encoded by Shab. J Neurosci. 1995; 15 (7 Pt 2): 5209-5221.

PubMed Abstract | Publisher Full Text 
Ussing $\mathrm{HH}$ : The active ion transport through the isolated frog skin in the light of tracer studies. Acta Physiol Scand. 1949a; 17(1): 1-37.

PubMed Abstract | Publisher Full Text

Ussing HH: Transport of ions across cellular membranes. Physiol Rev. 1949b; 29(2): 127-155.

PubMed Abstract | Publisher Full Text

Ussing $\mathrm{HH}$ : The distinction by means of tracers between active transport and diffusion. Acta Physiol Scand. 1949c; 19(1): 43-56.

Publisher Full Text

van't Hoff JH: Etudes de dynamique chimique. Muller, 1884; 1.

Reference Source

Venetucci LA, Trafford AW, O'Neill SC, et al:: $\mathrm{Na} / \mathrm{Ca}$ exchange: regulator of intracellular calcium and source of arrhythmias in the heart. Ann NY Acad SCi. 2007; 1099(1): 315-325.

PubMed Abstract | Publisher Full Text

Wiggins PM: The relationship between pump and leak: Part 1. application of the butler-volmer equation. Bioelectrochem Bioenerg. 1985a; 14(4-6): 313-326. Publisher Full Text

Wiggins PM: Relationship between pump and leak: Part 2. a model of the $\mathrm{Na}$, K-atpase functioning both as pump and leak. Bioelectrochem Bioenerg. 1985b;
14(4-6): 327-337.

Publisher Full Text

Wiggins PM: Relationship between pump and leak: Part 3. electrical coupling of $\mathrm{Na}^{+}$-solute uptake to the $\mathrm{Na}$, K-atpase. Bioelectrochem Bioenerg. 1985c; 14(4-6):

339-345.

Publisher Full Text

Willms AR, Baro DJ, Harris-Warrick RM, et al:: An improved parameter estimation method for Hodgkin-Huxley models. J Comput Neurosci. 1999; 6(2): 145-168.

PubMed Abstract | Publisher Full Text

Woodbury JW: Eyring rate theory model of the current-voltage relationships of

ion channels in excitable membranes. Advances in Chemical Physics: Chemical

Dynamics: Papers in Honor of Henry Eyring. 1971; 21: 601-617.

Publisher Full Text

Yue DT, Backx PH, Imredy JP: Calcium-sensitive inactivation in the gating of single calcium channels. Science. 1990; 250(4988): 1735-1738.

PubMed Abstract | Publisher Full Text

Zhang $\mathrm{H}$, Holden AV, Kodama I, et al:: Mathematical models of action potentials in the periphery and center of the rabbit sinoatrial node. Am J Physiol Heart

Circ Physiol. 2000; 279(1): H397-H421.

PubMed Abstract | Publisher Full Text 


\section{Open Peer Review}

\section{Current Peer Review Status:}

\section{Version 1}

Reviewer Report 30 October 2018

https://doi.org/10.5256/f1000research.17657.r38997

(C) 2018 Santillán M. This is an open access peer review report distributed under the terms of the Creative Commons Attribution License, which permits unrestricted use, distribution, and reproduction in any medium, provided the original work is properly cited.

\section{Moisés Santillán}

Moisés Santillán's Quantitative Biology \& Complex Systems Lab, Center for Research and Advanced Studies of the National Polytechnic Institute (CINVESTAV), Monterrey, Nuevo León, Mexico

I found this paper quite interesting. It introduces a mathematical formulation for ion transport across cell membranes, based in thermodynamic principles. The author further shows that other, more common formulations, are special cases of the more general one introduced here. Finally, the author employs the introduced formulation to study the dynamics of SA pacemaker cells, and is able to explain the experimentally-observed double activation of calcium channels.

Overall, I have a good opinion of this paper and recommend its indexing. There are only a few minor points that should be addressed:

1. Page 3, first column, beginning of last paragraph: Eq. (10) is referred to before being introduced.

2. In my opinion, Eq. (8) is not self-evident, and its origin should be explained.

3. Same thing for Eq. (33).

4. The procedure to estimate the parameter values in Table 2 must be explained. Moreover, a parameter sensitivity analysis should be performed to assess the robustness of the obtained results.

Is the work clearly and accurately presented and does it cite the current literature? Yes

Is the study design appropriate and is the work technically sound? Yes 
Are sufficient details of methods and analysis provided to allow replication by others? Yes

If applicable, is the statistical analysis and its interpretation appropriate?

Not applicable

Are all the source data underlying the results available to ensure full reproducibility? No source data required

Are the conclusions drawn adequately supported by the results? Yes

Competing Interests: No competing interests were disclosed.

I confirm that I have read this submission and believe that I have an appropriate level of expertise to confirm that it is of an acceptable scientific standard.

Author Response 03 Nov 2018

Marco Arieli Herrera-Valdez, Universidad Nacional Autonoma de Mexico, CDMX, Mexico

The answers to comments made by reviewers are written in italics after each comment.

\section{Answers to comments from reviewer 2}

Overall, I have a good opinion of this paper and recommend its indexing. There are only a few minor points that should be addressed:

1. Page 3, first column, beginning of last paragraph: Eq. (10) is referred to before being introduced.

Corrected the error in the cross reference.

2. In my opinion, Eq. (8) is not self-evident, and its origin should be explained.

Added a reference pointing to a Boltzmann distribution.

3. Same thing for Eq. (33).

Added a reference for the work of Willms et al., 1999.

4. The procedure to estimate the parameter values in Table 2 must be explained. Moreover, a parameter sensitivity analysis should be performed to assess the robustness of the obtained results.

The reviewer points to a very important issue. There are different publications and books addressing the robustness of conductance-based models (which are similar to the current one), 
from a dynamical systems perspective, using bifurcation theory. That being said, I agree that the parameter sensitivity analysis should be done for completeness, as this is a different model, but that analysis is beyond the scope of this paper. Nevertheless, parameter sensitivity analysis is addressed in a publication currently in preparation. In that publication, I address a few issues, including whether the gating formulas yield correct predictions in consideration of the work of Hodgkin and Huxley and the powers used for the fits on voltage clamps, and whether the relationships between parameters are correct, as a consequence of the modeling using those powers. It is worth mentioning that the parameters are in line with the experimentally measured magnitudes for cardiocytes and neurons, as those being modeled.

Competing Interests: No competing interests to declare.

Reviewer Report 01 October 2018

https://doi.org/10.5256/f1000research.17657.r38363

(C) 2018 Wedgwood K. This is an open access peer review report distributed under the terms of the Creative Commons Attribution License, which permits unrestricted use, distribution, and reproduction in any medium, provided the original work is properly cited.

\section{Kyle C.A. Wedgwood}

Living Systems Institute, College of Engineering, Maths and Physical Sciences, Centre for Biomedical Modelling and Analysis, University of Exeter, Exeter, UK

Thank you for inviting me to review the article entitled "A thermodynamic description for physiological transmembrane transport". This article presents a unifying mathematical formulation for passive and active transport across plasma membranes. This is achieved by considering the energy required to achieve transport of the molecules. For active transport, in which molecules are transported against their concentration gradient, the required energy is positive. In contrast, passive movement down a concentration gradient does not require energy transfer. In previous modelling frameworks, active and passive transport have been described via distinct models for pumps and channels respectively. The major contribution of this paper is to combine these models into one formulation.

After presenting the initial mathematical formulation, the article proceeds to make comparisons with existing literature and demonstrates that earlier mathematical models of channels are special cases of the more general framework. The article ends with an example in which the full model can explain a double activation event of $\mathrm{Ca}^{2+}$ channels, which cannot be done so satisfactorily by existing models.

In general, the article is well-written, with arguments made concisely and coherently. Aside from a few points which require further clarification, I believe that this article is sufficiently rigorous and of interest to the community to warrant publication. In particular, channel and pump models have long been used in the mathematical study of excitability in cell membranes. These models have been used to support and guide experimental studies as well as advancing the applied 
mathematics field in its own right. As such, improvements to these models should be welcomed by the field.

I will now address specific issues with the article:

1. In general, I believe that the figure captions could do with expanding to guide the reader's eyes to the features of the plot that they should be focusing on.

2. p2, first paragraph: At present, the discussion of passive and active transport in the Introduction is a little confusing. In particular, there are transmembrane proteins that undergo conformational changes to transport molecules down their concentration gradient and channels that achieve this by effectively forming pores through the membrane (so that further conformational change is not needed to effect transport). Furthermore, the reference Blicher \& Heimberg, 2013 reports on spontaneous (protein-free) formation of channels in synthetic membranes. Whilst this is an interesting topic, it should be made clearer how this relates to physiological membranes. Finally, it might also be useful to the reader to give an example of how some of the different pump configurations work (e.g. uniporter, symporter) to facilitate understanding of where energy transfer is required.

3. p2, 3rd paragraph: "Examples of fits to..." This is not a sentence. Please revise.

4. p2, 3rd paragraph: The author should highlight what "noncentral issues" they are referring to.

5. p2, 5th paragraph, minor: It would be useful to highlight that $c_{s^{\prime}} d_{s} \backslash$ in $\{0,1\}$.

6. p2, Eq. (1): $v$ is not defined.

7. p2, footnote, minor: Change "log" to "In" here for consistency with Eq. (1) and (3).

8. p3, 2nd paragraph: It would be good to clarify in this first sentence the distinction between IDelta G and \Delta G_s (or avoid using the former entirely).

9. $\mathrm{p3}$, 2nd paragraph: $\mathrm{S}=\{\mathrm{Na}, \mathrm{H}\}$ typo here.

10. p3, Eq. (5): Similarly to point (7), it is not clear what IDelta G represents here.

11. p3, Eq. (6): Terms in this equation need defining properly in several regards. Firstly, IDelta G ATP $^{0}$ should be defined. Secondly, it should be made clear that concentrations are intracellular (as opposed to in Eq. (1) (3), which correspond to both extra- and intracellular compartments). This is particularly confusing for $P_{i}$ in which the subscript could easily be misread as being an intracellular label. Finally, it is not clear how the equality $\backslash$ Delta $\mathrm{GA}_{\mathrm{TP}}=$ $\mathrm{qv}_{\text {ATP }}$ holds. Perhaps, as in footnote (1), it could be made clear that this relies on the definition of the reversal potential for ATP.

12. p3, Eq. (6): I would also here like to take the opportunity to raise a point about the general framework. The models here account for the energy required to move molecules with and against their concentration gradients. In cases of active transport, as indicated by Eq. (10), ATP is then hydrolysed to meet the energy deficit required to power the pump. This then 
means that the concentration of ATP, relative to ADP is then changing. Indeed, at maximal rates of exercise, the ATP concentration in skeletal muscle can fall by up to $20 \%$ of its initial value. Moreover, in certain cell types, local ratios between ATP and ADP affect the opening and closing of ion channels (e.g. $\mathrm{K}_{\text {ATP }}$ ). Eq. (10) implies that ATP and ADP in the cell are constant, in spite of the necessity that it must change. One must, therefore, conclude that an assumption is being made that ATP changes are small relative to the total amount of ATP. This assumption should be stated, or a discussion around how changes to ATP concentrations effect Eq. (10) should be made.

13. p3, final paragraph of first column: Wrong equation being referred to.

14. p3, Eq. (9): A physical interpretation for parameters $r$ and b should be given. Additionally, and referring back to my previous comment (1), the text here discusses the relative magnitudes of $r$ for electrodiffusive and active transport. Thus, this point should make clear that ion channels should be faster than both facilitated diffusion through carrier proteins and active transport via pumps.

15. p4, Eq. (11): For consistency with Eq. (5), 'Extra' in the subscripts should read 'Ext'. Also, it should be noted that $v_{\text {Extra }}$ should be the $v_{\text {ATP }}$ from Eq. (6).

16. p4, "In particular, for electrodiffusive (passive) transport of ions of type I": It is not clear what the author is referring to here (or how it is different from what is written in Eq. (15)).

17. p4, "The first, more complex form...": Does the author mean to reference Eq. (11) here?

18. p4, After Eq. (16), minor: "Ampere" needs capitalising.

19. p5, Table 1: Is $v_{0}$ here the same as in Eq. (15)? If so, the dependency on $v_{\text {Ext }}$ seems to have disappeared.

20. p6, Fig. 2: What is plotted on the ordinate axis in this graph? It appears to have units of pA, but the text says that this is a plot of alpha/beta, which should be dimensionless.

21. p8, "Electrodiffusive transport": I'm not really sure what the point of this section is since the results presented here have mostly been mentioned previously in this manuscript.

22. p8, after Eq. (31): Is the $N$ written here supposed to be $N_{-}$I? Also, there is a typo after Eq. (31) (with $\rightarrow$ where).

23. p9, Eq. (33): $\mathrm{m}$ is not defined.

24. p9, Eq. (35-39): Change symbol for current to $i_{x}$ for consistency with previous equations.

25. p9, after Eq. (39): Presumably, the author here means that the intracellular $\mathrm{Ca} 2+$ concentration changes (rather than the extracellular). This should be clarified. Also, the text below Eq. (40) appears to imply a distinction between free and bound $\mathrm{Ca}^{2+}$, but there is no buffering process described in the model, which may cause confusion. 
26. p9, Fig. 2: Please state what $i_{m}$ and $i_{C a L 13}$ are in these plots.

27. p10, Table 2: The units of $\backslash$ bar $\{a\}$ are inconsistent with the main text.

28. p12, "Another possible use of the third order approximations is in the construction of network models.": Please could the author state what they mean here?

29. p13, discussion on action potential shape: I was wondering if the author could here compare their argument surrounding the shape of the action potential near initiation with those put forward here (Brette, $2013^{1}$ ), which puts forward a case for multi-compartment models to describe the sharpness of the spike.

30. SI1, after (A3): There appears to be a reference missing here.

31. SI2: Headers are required in these data files so that the values herein can be related to the physical quantities they represent.

32. It would be useful for the author to upload any code used to generate the plots in the article.

\section{References}

1. Brette R: Sharpness of spike initiation in neurons explained by compartmentalization.PLoS Comput Biol. 2013; 9 (12): e1003338 PubMed Abstract | Publisher Full Text

Is the work clearly and accurately presented and does it cite the current literature? Yes

Is the study design appropriate and is the work technically sound?

Yes

Are sufficient details of methods and analysis provided to allow replication by others? Yes

If applicable, is the statistical analysis and its interpretation appropriate? Not applicable

Are all the source data underlying the results available to ensure full reproducibility? Partly

Are the conclusions drawn adequately supported by the results?

Yes

Competing Interests: No competing interests were disclosed.

I confirm that I have read this submission and believe that I have an appropriate level of expertise to confirm that it is of an acceptable scientific standard, however I have 


\section{significant reservations, as outlined above.}

Author Response 02 Nov 2018

Marco Arieli Herrera-Valdez, Universidad Nacional Autonoma de Mexico, CDMX, Mexico

The answers to comments made by reviewers are written in italics after each comment.

\section{Answers to comments from Reviewer 1}

Thank you for inviting me to review the article entitled "A thermodynamic description for physiological transmembrane transport". This article presents a unifying mathematical formulation for passive and active transport across plasma membranes. This is achieved by considering the energy required to achieve transport of the molecules. For active transport, in which molecules are transported against their concentration gradient, the required energy is positive. In contrast, passive movement down a concentration gradient does not require energy transfer. In previous modelling frameworks, active and passive transport have been described via distinct models for pumps and channels respectively. The major contribution of this paper is to combine these models into one formulation.

After presenting the initial mathematical formulation, the article proceeds to make comparisons with existing literature and demonstrates that earlier mathematical models of channels are special cases of the more general framework. The article ends with an example in which the full model can explain a double activation event of Ca2+ channels, which cannot be done so satisfactorily by existing models.

In general, the article is well-written, with arguments made concisely and coherently. Aside from a few points which require further clarification, I believe that this article is sufficiently rigorous and of interest to the community to warrant publication. In particular, channel and pump models have long been used in the mathematical study of excitability in cell membranes. These models have been used to support and guide experimental studies as well as advancing the applied mathematics field in its own right. As such, improvements to these models should be welcomed by the field.

Thank you for your comments. They make the article clearer and better.. Please find answers to each of them below.

I will now address specific issues with the article:

1. In general, I believe that the figure captions could do with expanding to guide the reader's eyes to the features of the plot that they should be focusing on.

I have added phrases pointing to specific parts of the graphs or mentioning specific things to notice in each of the figures.

2. p2, first paragraph: At present, the discussion of passive and active transport in the Introduction is a little confusing. In particular, there are transmembrane proteins that undergo conformational changes to transport molecules down their concentration gradient and channels that achieve this by effectively forming pores through the membrane (so that further conformational change is not needed to effect transport). Furthermore, the reference Blicher \& Heimberg, 2013 reports on spontaneous (protein-free) formation of 
channels in synthetic membranes. Whilst this is an interesting topic, it should be made clearer how this relates to physiological membranes. Finally, it might also be useful to the reader to give an example of how some of the different pump configurations work (e.g. uniporter, symporter) to facilitate understanding of where energy transfer is required.

The first paragraph in p2 has been rewritten taking into account the above observations.

3. p2, 3rd paragraph: "Examples of fits to..." This is not a sentence. Please revise.

Thank you, corrected.

4. p2, 3rd paragraph: The author should highlight what "noncentral issues" they are referring to.

Rewrote the paragraph for clarity and punctuality.

5. p2, 5th paragraph, minor: It would be useful to highlight that $c s, d s \backslash i n\{0,1\}$.

Highlighted

6. p2, Eq. (1): $v$ is not defined.

\section{Added definition}

7. p2, footnote, minor: Change "log" to "In" here for consistency with Eq. (1) and (3).

\section{Changed log to In}

8. p3, 2nd paragraph: It would be good to clarify in this first sentence the distinction between IDelta G and IDelta G_s (or avoid using the former entirely).

\section{Corrected.}

9. p3, 2nd paragraph: $\mathrm{S}=\{\mathrm{Na}, \mathrm{H}\}$ typo here.

\section{Corrected.}

10. p3, Eq. (5): Similarly to point (7), it is not clear what IDelta G represents here.

\section{Added a phrase to explain it.}

11. p3, Eq. (6): Terms in this equation need defining properly in several regards. Firstly, IDelta GATPO should be defined. Secondly, it should be made clear that concentrations are intracellular (as opposed to in Eq. (1) (3), which correspond to both extra- and intracellular compartments). This is particularly confusing for $\mathrm{Pi}$ in which the subscript could easily be misread as being an intracellular label. Finally, it is not clear how the equality $\backslash$ Delta GATP= qvATP holds. Perhaps, as in footnote (1), it could be made clear that this relies on the 
definition of the reversal potential for ATP.

Added square brackets and subindices to indicate that the intracellular concentrations of ADP, ATP, and Pi are intracellular. Also corrected a typo, there was an extra $q$ in the term for \$IDelta G_O\$

12. p3, Eq. (6): I would also here like to take the opportunity to raise a point about the general framework. The models here account for the energy required to move molecules with and against their concentration gradients. In cases of active transport, as indicated by Eq. (10), ATP is then hydrolysed to meet the energy deficit required to power the pump. This then means that the concentration of ATP, relative to ADP is then changing. Indeed, at maximal rates of exercise, the ATP concentration in skeletal muscle can fall by up to $20 \%$ of its initial value. Moreover, in certain cell types, local ratios between ATP and ADP affect the opening and closing of ion channels (e.g. KATP). Eq. (10) implies that ATP and ADP in the cell are constant, in spite of the necessity that it must change. One must, therefore, conclude that an assumption is being made that ATP changes are small relative to the total amount of ATP. This assumption should be stated, or a discussion around how changes to ATP concentrations effect Eq. (10) should be made.

Added a comment about the assumptions and a comment about the possibility of changes in concentration for ATP, ADP, and Pi

13. p3, final paragraph of first column: Wrong equation being referred to.

\section{Corrected cross reference}

14. p3, Eq. (9): A physical interpretation for parameters $r$ and $b$ should be given.

Additionally, and referring back to my previous comment (1), the text here discusses the relative magnitudes of $r$ for electrodiffusive and active transport. Thus, this point should make clear that ion channels should be faster than both facilitated diffusion through carrier proteins and active transport via pumps.

Added clarification and phrases providing interpretation for the two parameters.

15. p4, Eq. (11): For consistency with Eq. (5), 'Extra' in the subscripts should read 'Ext'. Also, it should be noted that vextra should be the VATP from Eq. (6).

Added clarification and deleted the " $r a$ " in the extra suffix.

16. p4, "In particular, for electrodiffusive (passive) transport of ions of type I": It is not clear what the author is referring to here (or how it is different from what is written in Eq. (15)).

Rephrased the sentence for correction.

17. p4, "The first, more complex form...": Does the author mean to reference Eq. (11) here?

Moved the sentence up to the paragraph with Eq. (11) and added the cross reference 
18. p4, After Eq. (16), minor: "Ampere" needs capitalising.

\section{Corrected}

19. p5, Table 1: Is v0 here the same as in Eq. (15)? If so, the dependency on vExt seems to have disappeared.

$v E x t$ is not written in those cases where it is zero.

20. p6, Fig. 2: What is plotted on the ordinate axis in this graph? It appears to have units of $\mathrm{pA}$, but the text says that this is a plot of alpha/beta, which should be dimensionless.

\section{Corrected text.}

21. p8, "Electrodiffusive transport": I'm not really sure what the point of this section is since the results presented here have mostly been mentioned previously in this manuscript.

Added sentences making the point more explicit and took away the sentence in previous paragraphs where the single ion energy was discussed to avoid repetition.

22. p8, after Eq. (31): Is the $\mathrm{N}$ written here supposed to be $\mathrm{N}_{-}$I? Also, there is a typo after Eq. (31) (with $\rightarrow$ where).

Changed $N$ for $M$ to avoid confusion.

23. p9, Eq. (33): $\mathrm{m}$ is not defined.

Changed the order in which equations are presented and rephrased so that variables and parameters are better explained

24. p9, Eq. (35-39): Change symbol for current to ix for consistency with previous equations.

The currents in equations 35-39 are normalized by the membrane capacitance. Therefore, to avoid abuse of notation, added a note remarking the change in the letter for the functions, explaining it is due to normalization.

25. p9, after Eq. (39): Presumably, the author here means that the intracellular Ca2+ concentration changes (rather than the extracellular). This should be clarified. Also, the text below Eq. (40) appears to imply a distinction between free and bound $\mathrm{Ca} 2+$, but there is no buffering process described in the model, which may cause confusion.

Added sentences to clarify these points.

26. p9, Fig. 2: Please state what im and iCaL13 are in these plots.im represents the total current. 
Added a sentence to the figure caption.

27. p10, Table 2: The units of $\operatorname{Vbar}\{a\}$ are inconsistent with the main text.

Corrected by deleting the bars in the table for normalized amplitude entries. $I b a r\{a\}$ is in $p A, a=$ Ibar $\{a\} / C m$ in $p A / p F$

28. p12, "Another possible use of the third order approximations is in the construction of network models.": Please could the author state what they mean here?

Expanded the sentence to clarify the point. The idea is to use cubic approximations to build network models taking advantage of the possible reduction in computational cost. However, as is explained in the paragraph, cubic approximations need to be tested first to address possible issues that may arise from using approximations.

29. p13, discussion on action potential shape: I was wondering if the author could here compare their argument surrounding the shape of the action potential near initiation with those put forward here (Brette, 20131), which puts forward a case for multi-compartment models to describe the sharpness of the spike.Added a comment about the results in the paper by Brette, 2013.

Thank you for pointing it out. Added a reference to his work too.

30. SI1, after (A3): There appears to be a reference missing here.

Edited the reference, it is for Equation 31.

31. SI2: Headers are required in these data files so that the values herein can be related to the physical quantities they represent.

Edited data files to include headers.

32. It would be useful for the author to upload any code used to generate the plots in the article.

Uploaded the code in an jupyter notebook.

Competing Interests: The author declares no competing interests. 
The benefits of publishing with F1000Research:

- Your article is published within days, with no editorial bias

- You can publish traditional articles, null/negative results, case reports, data notes and more

- The peer review process is transparent and collaborative

- Your article is indexed in PubMed after passing peer review

- Dedicated customer support at every stage

For pre-submission enquiries, contact research@f1000.com 